ISSN: 2146-3042

DOI: $10.25095 /$ mufad.579944

\title{
Muhasebe Ĕ̆itimi Alan Öğrencilerin Etik Konusunda Tutumları: Kütahya Araştırması
}

\author{
Selçuk YALÇIN*
}

\section{ÖZET}

Meslek mensuplarının etik değerlere bağlllı̆̆ hem verilen hizmetin kalitesini hem de mesleğin itibarını artırtr. Bu kapsamda Türkiye Serbest Muhasebeci Mali Müş̧avirler ve Yeminli Mali Müşavirler Odaları Birliği de muhasebe meslek mensuplarının uyacakları etik ilkeleri düzenlemiştir. Bu çalı̧̧mada söz konusu düzenleme doğrultusunda, Yalçın (2011) tarafindan hazırlanan anket formu Kütahya Dumlupınar Üniversitesi Uygulamalı Bilimler Yüksekokulu Muhasebe Bölümü ögrencilerine uygulanmıştır. Çalışmada betimsel istatistik ve gruplar arasındaki farkları tespit amacıyla bağımsız gruplar t testleri ile tek yönlü anova testleri uygulanmııstır.

Katılımcıların önemli ölçüde mezuniyet sonrası mesleki stajını başlatmayı düşündüğü, muhasebe meslek mensubu olmanın zor olmasına rağmen bunu istedikleri ve gelecekte ruhsat sahibi olarak kendi işyerinde çalışmayı tercih ettikleri görülmektedir. Bu konudaki ifadelere ticaret lisesi mezunları daha yüksek oranlarda katılım göstermişlerdir. Etik değerler doğrultusunda hazırlanan ifadelere genelde katılım yönünde tutum belirtilmiştir. Bununla birlikte ticaret lisesi mezunlarının etik değerler konusunda daha bilinçli oldukları ve ögrencilerin eğitim aşamaları ilerledikçe etik bilinçlerinin arttığl görülmektedir.

Anahtar Kelimeler: Etik, Muhasebe Meslek Etiği, Tutum, Eğitim, TÜRMOB.

JEL Sinıflandırması: M41, M14, L84.

\section{The Attitudes Of The Students Receiving Accounting Education On Ethics: Kütahya} Research

\section{ABSTRACT}

Professionals' commitment to ethical values increases both the quality of the service provided and the reputation of the profession. In this context, the Union of Certified Public Accountants and Sworn-in Certified Public Accountants of Turkey set up the principles of ethics for its members. In this study, the survey prepared by Yalçın (2011) was applied to the students of Accounting Department of Kütahya Dumlupinar University School of Applied Sciences. In this study, descriptive statistics, independent-samples t-tests and one-way anova tests were applied to determine the differences between the groups.

It is seen that; the participants significantly consider starting their internship after graduation; although it is difficult to be a professional accountant they want and they prefer to work in their own workplaces as a holder of license in the future. Commercial high school graduates shared in the statements in this subject at higher rates. The statements prepared in line with the ethical values are generally indicated in the attitude towards share. However, it is seen that graduates of commercial high schools are more conscious about ethical values and that their ethical consciousness increases as the students' education stages progress.

Keywords: Ethics, Accounting Profession Ethics, Attitude, Education, TURMOB.

Jel Classification: M41, M14, L84.

Makale Türü: Araştırma makalesi

\footnotetext{
*Doç. Dr., Kütahya Dumlupınar Üniversitesi, Uygulamalı Bilimler Yüksekokulu, selcuk.yalcin@dpu.edu.tr, ORCID ID: 0000-0002-9402-7524.
} 


\section{GíRIŞ}

Etik insan davranışlarının doğru ya da yanlış olarak değerlendirilmesinde kullanılan, insan ilişkilerinin düzenlenmesinde insanın kendisini kontrol etmesini sağlayan, yasal gereklerin ötesinde ilke ve kurallardır. Mesleki kuruluşlar mesleğin itibarını korumak ve arttırmak ve sunulan ürün veya hizmet kalitesini yükseltmek amacıyla çeşitli düzenlemeler yapmaktadırlar. TÜRMOB tarafindan Uluslararası Muhasebe Federasyonu'nun etik düzenlemelerine dayalı olarak hazırladığı "Serbest Muhasebeciler, Serbest Muhasebeci Mali Müşavirler ve Yeminli Mali Müşavirlerin Mesleki Faaliyetlerde Uyacakları Etik İlkeler Hakkında Yönetmelik” 19 Ekim 2007 tarih ve 26675 Sayllı Resmi Gazete'de yayınlanmıştır. $\mathrm{Bu}$ yönetmelik çalı̧̧mada etik yönetmeliği olarak ifade edilecektir.

Çalışmamızda Kütahya Dumlupınar Üniversitesi Uygulamalı Bilimler Yüksekokulu Muhasebe Bölümü öğrencilerinin, TÜRMOB Etik İlkeler Yönetmeliği doğrultusunda hazırlanan anket formu vasitasıyla, muhasebe meslek etiği konusundaki tutumları araştırılmıştır. Ayrıca katılımcıların ankette sunulan ifadelere verdikleri cevapların daha önce mezun oldukları ortaöğretim kurumları ve öğrenim gördükleri sınıflar itibariyle farklılaşıp farklılaşmadığının analizleri bağımsız gruplar t-testi (2-tiled) ve tek yönlü anova tekniği ile yapılmıştır.

Çalışma, ağılıklı olarak muhasebe derslerinden oluşan bir müfredat uygulayan ve öğrencilerinin büyük bölümüne muhasebe eğitimi verilen bir ortaöğretim kurumundan mezun olan bir bölümde yapılmıştır. Diğer taraftan çalışmanın tek bir bölümle sınırlı tutulması çalışmanın kısıtı olarak belirtilebilir.

\section{KAVRAMSAL ÇERÇEVE}

Meslek mensuplarının etik ilkelere bağll1ıkları sunulan ürün ve hizmetlerin kalitesini etkilediği kadar mesleğin itibarını da etkilemektedir. Bu yüzden son yıllarda etik konusu önem kazanmıştır. Etik sözcüğü Yunanca "karakter" anlamına gelen "ethos" sözcüğünden türetilmiştir (Aydın, 2002: 4). Etik, yasal gerekleri aşan ölçüde kendini kontrol demek olan ideal bir insan özelliğidir (Selimoğlu, 2006: 438). Etik doğru ve yanlış kavramları ile ilgilidir. Etik' in konusu, insan ilişkilerinin özünü teşkil etmektedir. Etik' in temel konusu, bir insanın bir başka insana davranış biçimini ve o insanın başkalarından beklediği davranış biçimlerini içermektedir. Etik ilkeler, doğru ve iyi davranışların oluşması ve geliştirilmesini hedefler (Ay, 2003: 59). Etik kurallar, neyin doğru, neyin yanlış olduğuna işaret etmekte ve kişilere, gruplara ve toplumlara yol göstermektedir (Akbaş, Özsözgün ve Özarslan, 2009: 175). Etik, insanlar arasındaki ilişkilerin temelinde yer alan değerleri, ahlaki bakımdan iyi ya da kötü, doğru ya da yanlış olanın niteliğini ve temellerini araşııran felsefe alanıdır (Yıldız, 2002: 17). Etik, ahlaki davranış eylem ve yargıları ilgilendiren bir konu olarak felsefe ve bilimin önemli bir parçası ve sistematik bir çalışma alanı olmuştur (Aydın, 2002: 3). Etik ahlaki standartların hayata uygulanışının ve mantıklı olup olmadıklarının sorgulanmasıdır; yani bir bakıma muhakeme ve akıl yürütme sürecidir (Tevrüz, 2007: 2). Günümüzde, etik ve ahlak, eş anlamda kullanılmakla birlikte, farklı kavramlardır. Ahlak insanların nasıl davranması gerektiği hakkındaki düsturlardır (Tevrüz, 2007: 2). Etik, ister bireysel olsun, ister kolektif, bir öznenin pratiğini yargılayan ilkedir (Badiou, 2004: 17). Ahlak felsefesi ya da etik, ahlakı konu edinen felsefe dalıdır (Aydın, 2002: 3). Ahlak, huy, mizaç, yaratılış anlamına gelen "hulk" sözcüğünün çoğulu olup, insanlar arası ilişkilerde uyulması gereken tinsel (manevi) 
ilke ve kuralları içerir. Ahlakın etkisi, yaptırımı, zorlayıcı gücü, insanın vicdanıdır. İnsan, duygusunu, düşüncesini, davranışını, tutumunu, eylemini "vicdanının sesine" kulak vererek doğru-yanlış, güzel-çirkin, iyi-kötü, olumlu-olumsuz olarak değerlendirir (Aydın, 2002: 4). Kısaca ahlak yaşanan bir olgudur; etik ise bu olguyu sorgulayan felsefe dalıdır ve felsefenin en eski temel disiplinlerinden biridir (Tevrüz, 2007: 2). Etik ilkeler bir örgüt içinde etiğin kurumsallaşması için, örgütün genel değerler sistemi ve amaçlarını tanımlayan, verilen kararların bu ilkelere uygunluğu için rehberlik eden mekanizmadır (Aydın, 2002: 2). Kuşkusuz, her toplum için uygulanacak standart etik ilkeler yoktur, yani etik kurallar toplumdan topluma farklılık gösterebilmektedir, hatta toplum içinde de çoğu zaman farklılıklar yaşanmaktadır (Akbaş vd, 2009: 175).

Her toplumda ve her meslekte meslek etiğine ihtiyaç vardır ve mesleki kuruluşlar mesleki etik kurallar geliştirmektedirler. Meslek mensubunun özgür seçimini yapabildiği alan ile yasal düzenlemelerle sınırlanan alan arasında yer alan boşluk etiksel yargı ile dengelenmektedir (Akdoğan, 2005: 296). Meslek etiği, özellikle doğrudan doğruya insanla ilgili mesleklerde uyulması gereken davranış kuralları olarak tanımlanabilir (Aydın, 2002: 75). Meslek etiği, genel anlamdaki etik yaklaşımlarının meslek alanlarında somutlaşan biçimleridir (Yıldız, 2002: 20). Mesleki etik, belirli bir meslek grubunun, mesleğe ilişkin olarak oluşturup, koruduğu, meslek üyelerine emreden, onları belli bir şekilde davranmaya zorlayan; kişisel eğilimlerini sınırlayan; yetersiz ve ilkesiz üyeleri meslekten dışlayan; meslek içi rekabeti düzenleyen ve hizmet ideallerini korumayı amaçlayan mesleki ilkeler bütündür (Aydın, 2002: 3). Meslek etiğinin temelini bireysel etik, işletme etiği ve toplumsal etik oluştururken; toplum, müşteriler, rakipler, hissedarlar, yasal ve siyasal çevreyi oluşturan kurumlar da meslek etiğini etkileyen dış çevre etkenleri olarak karşımıza çıkmaktadır (Akdoğan, 2003: 11).

Meslek etiği oluşturulurken amaçlanan, standart değerler oluşturmak ve bu değerleri evrensel niteliğe taşıyabilmektir. Bu sayede mesleğe özgü ortaya çıkan bu durum, hem iş hayatında bir güven ortamı yaratacak hem de toplumsal temelde ve uzun vadede sağlam alt yapılar sağlanmış olacaktır (Akbaş vd, 2009: 175). Son yıllarda ABD ve tüm dünyada yankı uyandıran Enron, Anderson Worldwide, Adelphia Communications, Bristol-Myers Squibb, CMS Energy, Merrill Lynch (ML), Xerox gibi şirketlerde yaşanan muhasebe skandalları meslek etiği anlayışında bir dönüm noktası olmuştur (Kısakürek ve Alpan, 2010: 217). Zira yaşanan skandalların nedenleri arasında düşük seviyede şeffaflık, çalışanlarda artış gösteren parasal güdüler ve örgüt kültürünün bozuk yapısı gibi etik dışı davranışlara motivasyon sağlayan etmenler söz konusudur (Kurt, Okan ve Başer, 2010: 3). Böylece muhasebe meslek etiğinin önemi bir kez daha ortaya çıkmıştır. Muhasebe mesleğine yönelik toplumsal güvenin korunması ve mesleğin kredibilitesinin arttırılması muhasebe meslek mensuplarının etik değerlere sahip olmaları ile sağlanabilir (Daştan, 2009: 282). Muhasebede etik; kanunlara uygun işlemlerin yanı sıra toplumun güncel değer yargılarına da önem vererek güvenilir bilgilerin topluma sunulmasıdır (Sözbilir, 2000: 46). Muhasebe meslek etiği; muhasebe meslek mensuplarınca gerek faaliyetlerin yürütülmesi sırasında, gerekse herhangi bir sebeple mesleki faaliyetin yürütülmediği durum ve dönemlerde, kanunlara uygun işlemlerin yapılması yanında, toplumum değer yargılarına da önem verilerek, güvenilir bilgilerin topluma sunulması ve müşteriler, toplum, meslektaşlar ve ilgili meslek kuruluşları ile olan ilişkilerde uyulması gereken kurallar bütünüdür (Daştan, 2009: 285). 
Muhasebe mesleğinin gelişimiyle birlikte AICPA (Amerikan Kamu Muhasebecileri Enstitüsü), IFAC (Uluslararası Muhasebe Federasyonu) ve Avrupa Birliği muhasebe etiği konusunda düzenlemeler yapmıştır. Ülkemizde de Sermaye Piyasası Kurulu (SPK), TÜRMOB ve Kamu Gözetimi, Muhasebe Denetimi Kurumu (KGK) muhasebe ve denetim meslek mensuplarına yönelik etik kurallar konusunda düzenlemeler yapmıştır.

TÜRMOB tarafindan 2007 yllında yayınlanan etik yönetmeliğinde yer alan etik komite 08.04.2018 tarih ve 30385 sayılı Resmi Gazetede yayınlanan yönetmelikle, etik kurul haline getirilmiş ve çalışma esasları tekrar belirlenmiştir. 27.03.2014 tarih ve 28954 sayılı Resmi Gazete'de Muhasebe Meslek Mensuplarının Etik Eğitimi ve Etik Sözleşme Yapması Hakkında Tebliğ yayınlanmıştır. Diğer taraftan bağımsız denetim konusunda düzenleyici otorite olan KGK, Türkiye Denetim Standartları doğrultusunda hazırlanan Bağımsız Denetçiler İçin Etik Kurallar Standardını 21.05.2015 tarihli ve 29362 sayılı Resmi Gazete'de yayınlamıştır. Standardın son sürümü 30/11/2017 tarihli ve mükerrer 30256 sayılı Resmi Gazete'de yayınlanmıştır. Böylece serbest muhasebeci mali müşavir ve yeminli mali müşavirler TÜRMOB'un yayınladığı etik yönetmeliğini; denetçiler ise KGK'nın yayınladığı etik standartları uygulayacaklardır. Her iki düzenlemede de temel etik kurallar benzer olmakla birlikte çalışmada TÜRMOB etik yönetmeliği esas alınmıştır.

\section{LITERATÜR TARAMASI}

Muhasebe meslek etiği konusunda ülkemizde pek çok çalışma yapılmıştır. Karabınar ve Çevik (2014) muhasebe meslek örgütü tarafindan getirilen etik kuralları maddeler özelinde ahlak felsefesi açısından incelemiştir. Çalışmada incelenen kuralların genel olarak deontolojik etik yaklaşımına uygun olduğu raporlanmıştır. Peker, Özdemir, Polat ve Karakışla (2016) Türkiye'de meslek etiği, muhasebe etiği, muhasebe etik eğitimi ve etik ilkeler üzerine yapılan çalışmalar üzerine literatür taraması yapmıştır. Muhasebe eğitimi alan muhasebe meslek mensubu adaylarının etik konusundaki tutumlarını araştırmak üzere çeşitli çalışmalar yapılmıştır. Kurnaz ve Gümüş (2010) muhasebe eğitimi alan öğrencilerin muhasebe mesleğiyle ilgili etik olmayan davranışlara ilişkin algılamalarını belirlemek amacıyla bir anket çalışması yapmıştır. Çalışmada katılımcıların büyük çoğunluğunun muhasebe mesleğiyle ilgili etik olmayan davranışları onaylamadığı̆, öğrencilerin bulundukları sınıflar itibariyle bu algılarının farklılaștı̆ı ve kadın katılımcıların bu konuda daha hassas oldukları sonuçlarına ulaşılmıştır. Yanık, Yıldız ve Günce (2013) Kocaeli Üniversitesi'nde yer alan Muhasebe ve Vergi Uygulamaları Programlarındaki öğrencilerinin muhasebe ile ilgili etik algılarını ölçmek amacıyla bir anket uygulaması yapmışlardır. Çalışmada öğrencilerin cinsiyetleri, doğup büyüdükleri yerler ve öğrencilerin annelerinin eğitimi ile etik ilkeler arasında istatistiksel olarak anlamlı farklılık olduğu; babalarının eğitimi ile etik ilkeler arasında anlamlı bir fark bulunmadığı raporlanmıştır. Uyar, Kahveci ve Yetkin (2015) Alanya Ticaret ve Sanayi Odası Meslek Yüksekokulu Muhasebe ve Vergi Uygulamaları Programı öğrencilerinin muhasebe meslek etiği algısını ölçmek amacıyla anket uygulaması yapmışlardır. Çalışmada öğrencilerin muhasebe mesleğinde etik dışı uygulamaların olduğuna yönelik algılarının olduğu ve meslek etiği dersi alan ve almayan öğrencilerin meslek etiğine ilişkin algılarında farklılık olmadığı belirtilmiştir. Ceylan ve Terzi (2016) Çankırı Karatekin Üniversitesi İşletme, İktisat ve Kamu Yönetimi Bölümü son sınıf öğrencilerinin mesleki etik kurallar konusunda bilgi, düşünce ve algılarını ölçmüştür. Çalışmada öğrencilerin meslek etiği algılamaları ile cinsiyet ve etik eğitim alıp almama durumları arasında anlamlı farklılık tespit edilirken; yaş, gelir düzeyi ve ikamet edilen yer arasında önemli düzeyde farklılık bulunmamıştır. Arslan, Gökoğlan ve 
Bulut (2018) Dicle Üniversitesi Sosyal Bilimler Meslek Yüksekokulu öğrencilerinin etik algılarını ölçmüştür. Çalışmada öğrencilerin mesleki etik ilke ve kurallara uyum ve uygulama konusunda kararsız oldukları ve meslek mensuplarının etik ilke ve kurallara gereken önemi vermediği ve mesleki eğitim ve seminerlerin yeterli düzeyde gerçekleştirilmediği konusunda görüş belirttikleri raporlanmıştır.

Ülkemizde muhasebe meslek mensuplarının etik ilkeler konusundaki tutumlarını ortaya koymak amacıyla çeşitli araştırmalar yapılmıştır. Aymankuy ve Sarıoğlan (2005) Balıkesir il merkezinde faaliyet gösteren meslek mensuplarının etik konusundaki yaklaşım ve algılamalarını araştırmak için bir anket uygulamışlardır. Çalışmada meslek mensuplarının mesleki etik konusunda kendilerini geliştirmeye istekli oldukları; bu konuda meslek odası, seminer, kurs, konferans ve kitaplardan yararlandıkları; meslek etiğini benimseyen ve benimsemeyenlerin oranının birbirine çok yakın olduğu raporlanmıştır. Çalışmada ayrıca katılımcıların çoğunluğunun yasal boşlukları mükellef lehine yorumladıkları ve mükellefler, yasalar ve elde edilen gelir farklılıklarının meslek mensuplarını etik dışı davranışlara zorladığı belirtilmektedir. Ertaş ve Arslan (2009) Çorum'da meslek mensuplarının etik kuralları algılama düzeylerini araştırmışlardır. Çalışmada etik kuralların algılanmasında bağımlı ve bağımsız çalışan muhasebeciler arasında anlamlı farklılık olmadığı; etik kuralların algılanmasının katılımcının mesleki unvan ve deneyimine göre değişmediği belirtilmiştir. Yalçın (2011) TÜRMOB etik yönetmeliği ile düzenlenen etik ilkelerin Türkiye'de bağımsız çalışan muhasebe meslek mensupları ve meslek mensuplarından hizmet alan işletmeler tarafından nasıl algılandığını araştırmak üzere bir anket çalışması yapmıştır. Çalışmada belirlenen temel etik ilkeler konusunda sunulan ifadelere meslek mensupları ve işletmelerin, bazı ifadelerde iki grup arasında farklılık tespit edilmesine rağmen, genelde katılım yönünde tutum ifade ettikleri raporlanmıştır. Fidan ve Subaşı (2014) İstanbul ilinde muhasebe meslek stajını yapanların etik ilkeler konusundaki değerlendirmelerini anket yoluyla incelemişlerdir. Çalışmada katılımcıların çoğunun etik eğitimi almadıkları, dörtte birinin stajları süresince etik kurallara aykırı davranışlar gözlemledikleri belirtilmektedir. Diğer taraftan mükellefi kaçırmama ve fazla kazanma eğilimlerinin meslek mensuplarını etik dışı davranışlara yönelttiği raporlanmıştır. Yücel ve Kartal (2014) muhasebe meslek mensuplarının mesleki uygulamalarındaki etik algılarını ve bunların mesleki faaliyetleri üzerindeki etkilerini incelemek amacıyla İstanbul ilinde anket uygulaması yapmışlardır. Çalışmada meslek mensuplarının haksız rekabet ve etik dışı davranışları ortaya konmuştur. Ayrıca meslek mensuplarının yarıya yakın bölümünün etik ilkelerin uygulanmasında önemli zafiyetlerin olduğuna inandığı belirtilmektedir. Yılmaz, Yıldırım ve Bahar (2015) Samsun ilinde bağımsız çalışan muhasebe meslek mensuplarının TÜRMOB etik yönetmeliğini nasıl algıladıkları ve genel etik değerler konusundaki görüşleri incelemek amacıyla anket uygulaması yapmışlardır. Çalışmada katılımcıların kıdem durumlarına göre dürüstlük, mesleki yeterlilik ve özen, gizlilik ve mesleki davranış boyutlarında farklılık olmadığı ancak genel etik algısı boyutunda farklılık olduğu raporlanmıştır. Ayrıca üniversiteler ve odaların işbirliği ile yapılacak meslek etiği eğitimleriyle farkındalığın arttırılabileceğgi belirtilmiştir. Daştan, Bayraktar ve Bellikli (2015) Trabzon ilinde meslek mensuplarının etik farkındalık düzeylerini ölçmüşlerdir. Çalışmada katılımcıların mesleki etik farkındalık düzeylerinin cinsiyet, eğitim düzeyi ve mesleki deneyimleri açısından farklılaştığı belirtilmektedir. Ayrıca meslek mensuplarının etik ilkeler doğrultusunda hareket etme bilincinde oldukları ve bunun yanı sıra müşterilerinin de bu bilinçle hareket etmeleri gerektiğine inandıkları raporlanmıştır. Dinç ve Tunçer (2015) vergi müfettişlerinin muhasebe meslek mensuplarının etik ilkelere duyarlılıkları ile ilgili 
algılarını ölçmüş ve bu algıları etkileyen çeşitli faktörlerin farklılık analizlerini yapmışlardır. Çalışmada vergi müfettişlerinin, muhasebe meslek mensuplarının tarafsızlık, dürüstlük, mesleki yeterlilik ve özen ile gizlilik ve profesyonel davranışlar konusunda oldukça yetersiz olduklarını düşündükleri raporlanmıştır. Kıllı, Türkoğlu ve Gülmez (2018) Malatya ilinde muhasebe meslek mensuplarının etik algıları, mesleği icra ederken yapılan etik dışı davranışlar ile ilgili genel görüşleri, etik dışı davranışlara neden olan faktörler ve çözüm önerileri ile ilgili görüşlerini araştırmak amacıyla anket uygulamışlardır. Çalışmada vergi oranlarının yüksekliği, devlet kurumlarındaki aşırı bürokrasi ve mesleğin hak ettiği değeri görememesinin etik dışı davranışlara yönelttiği belirtilmektedir. Ayrıca katılımcıların verdikleri cevapların cinsiyet, yaş, eğitim düzeyi, mesleki unvan, deneyim ve gelire göre farklılaşmadığı belirtilmektedir. Yel (2018) Bolu ilinde muhasebe meslek mensuplarının meslek etiğine uyumlu ve uyumsuz davranışlar sergilemelerinde rol oynayan nedenleri tespit etmek amacıyla anket uygulaması yapmıştır. Çalışmada sonuçları arasında mesleki itibarın kazançtan daha önemli olduğu, etik ilkelere bağlılığın mesleğin saygınlı̆ıını arttıracağı ve etik eğitiminin gerekliliği sıralanmıştır. Meslek etiğine uymada denetim, cezai ve vicdani yaptırımların, dini ve kültürel değerlerin etkili olacağı raporlanmıştır. Ayrıca etik dışı davranış nedenleri arasında mükelleflerin vergiden kaçınma isteğini ve meslek mensuplarının mükellef kaybetme kaygısı belirtilmiştir.

\section{YÖNTEM}

Bu çalışma Kütahya Dumlupınar Üniversitesi Uygulamalı Bilimler Yüksekokulu Muhasebe Bölümü öğrencilerinin TÜRMOB etik yönetmeliğini nasıl algıladıklarını ve temel etik değerler konusundaki tutumlarını araştırmaktadır. Bu amaçla, Yalçın (2011) tarafindan geliştirilen, bağımsız çalışan meslek mensupları ve bunlardan hizmet alan işletmelere aynı amaçla uygulanmış olan anket formu, bu çalışmada birincil veri toplamak amacıyla MayısHaziran 2018 döneminde öğrencilere uygulanmıştır. Anket formunda kullanılan ifadeler, TÜRMOB etik yönetmeliğinde tüm meslek mensuplarının uyması gereken ilkeler olarak belirlenen, dürüstlük, tarafsızlık, mesleki yeterlilik ve özen, gizlilik ve mesleki davranış ilkelerine dayalı olarak hazırlanmışıtır. Katılımcılar anket formundaki her bir ifade ile ilgili tutum derecesini Likert tipi 5'li ölçek doğrultusunda belirtmiştir.

Araştırmada verilerinin değerlendirilmesi amacıyla çeşitli istatistiki tekniklerden yararlanılmıştır. İşlemler SPSS 17 programında yapılmıştır. Verilerinin değerlendirilmesinde betimsel analiz kapsamında değişkenlere ilişkin aritmetik ortalama ve standart sapma değerleri incelenmiştir. Yordamsal analiz kapsamında ise katılımcıların verdikleri cevapların bulundukları gruplar itibariyle fark analizleri bağımsız örnek t-testi (2-tiled) ve tek yönlü anova ile yapılmıştır.

Araştırmanın evreni Kütahya Dumlupınar Üniversitesi Uygulamalı Bilimler Yüksekokulu Muhasebe Bölümü ögrencileridir. Örneklem olarak evrenin tamamı seçilmiştir. Ancak öğrencilerin tamamına anket ulaştırılamaması ve elde edilen anketlerin bir kısmının çalışmada kullanılamayacak şekilde özensiz doldurulması gibi sebeplerle anket geri dönüş oranı $\% 59$ olarak gerçekleşmiştir.

Likert ölçeği sıfırdan başlamadığı için katılımcıların cevaplarının değerlendirilmesinde Tablo 1'de yer alan aralıklar kullanılmıştır. Aralıkların eşit olduğu varsayılmış, aritmetik ortalamalar için puan aralığ 0,80 olarak aşağıdaki şekilde hesaplanmıştır. 
Puan Aralığ $1=($ En Yüksek Değer - En Düşük Değer $) / 5=(5-1) / 5=0,80$

Tablo 1. 5'li Likert Ölçeği Değerlendirme Aralıkları

\begin{tabular}{ll}
\hline Aralık & Seçenek \\
\hline $1,00-1,80$ & Kesinlikle katılmiyorum \\
$1,81-2,60$ & Katılmiyorum \\
$2,61-3,40$ & Kararsizım \\
$3,41-4,20$ & Katıliyorum \\
$4,21-5,00$ & Kesinlikle katıliyorum \\
\hline
\end{tabular}

Anketin güvenirlik çalışması, iç tutarlık katsayı (Cronbach alpha) değerleri hesaplanarak yapılmıştır. Cronbach alfa katsayısı, ölçek içinde bulunan maddelerin iç tutarlılığının (homojenliğinin) bir ölçüsüdür. Alfa katsayısı ölçekte yer alan k ifadenin varyansları toplamının genel varyansa oranlanması ile bulunan bir ağırlıklı standart değiş̧im ortalamasıdır (Özdamar, 1997: 493). İlgili ölçeğin alfa katsayısı yüksekse "bu ölçekte bulunan maddelerin o ölçüde birbirleriyle tutarlı ve aynı özelliğin öğelerini yoklayan maddelerden oluştuğu ya da tüm maddelerin o ölçüde birlikte çalıştığı" (Alpar, 2003: 381) şeklinde yorumlanır. ${ }^{1}$ Çalışmada kullanılan ölçekler için alfa katsayıları; anket formunun tamamı için 0,938; Genel Durum Ölçeği için 0,610 ve Etik Değerler Ölçeğinin Tamamı için 0,956 olarak hesaplanmıştır. Buna göre anket formunun tamamı ve Etik Değerler Ölçeğinin güvenilirliği yüksek derecededir. Genel Durum Ölçeği ise oldukça güvenilir bir ölçektir.

\section{ARASTIRMA BULGULARI}

Çalışma kapsamında katılımcılara uygulanan anketin değerlendirilmesinde sınıfları itibariyle öğrenci ve katılımcı sayıları ile etik ilkeler konusundaki değerlendirmeleri incelenmiştir.

\subsection{Demografik Özellikler}

Anketin uygulandığı bölümde, sınıfları itibariyle öğrenci sayıları, çalışmaya katılan öğrenci sayıları ile bunların oranları Tablo 2'de sunulmuştur. Yıllar itibariyle bölüme yerleşen öğrenci sayılarında değişiklik olmamasına rağmen üçüncü sınıfta yer alan öğrenci sayısının düşük olması öğrencilerin birinci ve ikinci sınıf başarılarının düşüklüğü ve bir üst sınıfa geçebilmek için belirlenen AKTS toplamına ulaşamamaları ile ilgilidir. Diğer taraftan, ikinci sınıf öğrenci sayısı biraz düşük olmakla birlikte, katılımcıların sınıflar itibariyle dağılımının genelde dengeli olduğu söylenebilir. Ayrıca katılımcıların \% 57'si muhasebe eğitimi veren bir ortaöğretim kurumundan mezun olmuştur.

\footnotetext{
${ }^{1}$ Cronbach Alfa Katsayısına bağlı olarak ölçeğin güvenilirliği aşağıdaki gibi yorumlanır (Kalaycı vd., 2006, 405; Alpar, 2003: 382):

$0,80 \leq \alpha \leq 1,00$ ise ölçek yüksek derecede güvenilir bir ölçektir, $0,60 \leq \alpha \leq 0,80$ ise ölçek oldukça güvenilir bir ölçektir, $0,40 \leq \alpha \leq 0,60$ ise ölçeğin güvenilirliği düşüktür, $0,00 \leq \alpha \leq 0,40$ ise ölçek güvenilir değildir.
} 
Tablo 2. Öğrenci ve Katılımcı Sayıları ile Oranları

\begin{tabular}{ccccc}
\hline Sınıf & Öğrenci & \% & Katılımcı & \% \\
\hline 1 & 151 & 28 & 91 & 29 \\
2 & 154 & 28 & 63 & 20 \\
3 & 86 & 16 & 68 & 21 \\
4 & 152 & 28 & 97 & 30 \\
Toplam & 543 & 100 & 319 & 100 \\
\hline
\end{tabular}

\subsection{Genel Değerlendirmeler}

Çalışmanın bu bölümünde katılımcıların genel durumunu analiz etmek üzere hazırlanan ifadelere verilen cevapların ortalama ve standart sapmaları ile katılımciların verdiği cevapların bulundukları sınıf ve mezun oldukları ortaöğretim kurumu itibariyle değişim gösterip göstermediğinin analizi yapılmıştır.

\subsubsection{Genel Durum Analizi}

Katılımcıların mevcut durumları ve gelecek beklentilerini araştırdığımız genel nitelikli ifadelere verdikleri cevapların ortalama ve standart sapmaları Tablo 3 'te sunulmuştur.

Tablo 3. Genel Durum Analizi Ortalama ve Standart Sapmaları

\begin{tabular}{lcc}
\hline & Ort. & SS. \\
\hline A1 Muhasebe mensubu olmayı istiyorum & 3,73 & 0,07 \\
\hline A2 Mezuniyet sonrası stajımı hemen başlatacağım & 3,62 & 0,07 \\
\hline A3 Muhasebe meslek elemanı olmak zor bir iş & 3,61 & 0,07 \\
\hline A4 Bu bölüme geldiğime memnunum & 3,22 & 0,07 \\
\hline A5 Gelecek 10 yılda belge sahibi olarak bir işyerinde çalışıyor olacağım & 3,61 & 0,07 \\
\hline A6 Gelecek 10 yılda belge sahibi olmadan bir işyerinde çalışıor olacağım & 2,27 & 0,07 \\
\hline A7 Gelecek 10 yılda kendi büromun sahibi olacağım & 3,36 & 0,07 \\
\hline A8 Gelecek 10 yılda belge sahibi olarak başkasının bürosunda olacağım & 2,58 & 0,06 \\
\hline A9 Gelecek 10 yılda belge sahibi olmadan başkasının bürosunda olacağım & 2,19 & 0,06 \\
\hline A10 Gelecek 10 yılda bağımsızı denetçi olacağım & 2,82 & 0,07 \\
\hline A11 Gelecek 10 yılda müfettiş benzeri devlet memuru olacağım & 2,87 & 0,06 \\
\hline A12 Gelecek 10 yılda muhasebe hayatımda olmayacak & 2,19 & 0,07 \\
\hline A13 Gelecek 10 yıllda öğretmen/akademisyen olacağım & 2,91 & 0,07 \\
\hline
\end{tabular}

Anket sonuçlarından elde edilen ortalamalardan, öğrencilerin mezuniyet sonrası hemen mesleki stajını başlatmayı düşündüğü; muhasebe meslek mensubu olmanın zor olmasına rağmen bunu istediği; gelecekte belge sahibi olarak kendi işyerinde çalışmayı istediği sonuçları ortaya çıkmaktadır. Diğer taraftan öğrencilerin bağımsız denetçi, devlet memurluğu veya öğretmenlik / akademisyenlik konusunda kararsız oldukları görülmektedir.

Katılımcıların A12 numaralı ifadeye verdikleri cevapların ortalaması $(2,19)$ katılmiyorum şeklindedir. Bu oran dikkate değerdir. Diğer taraftan A4 ifadesine verilen cevapların ortalaması $(3,22)$ öğrencilerin bu konuda kararsız olduklarını ve muhasebe bölümünden çok da memnun olmadıklarını göstermektedir. Bununla birlikte katılımcılar muhasebe meslek mensubu olmanın gelecekleri açısından önemli olduğunun farkındadırlar. Bu yüzden katılımcıların büyük bir kısmının hedef koyup çaba harcadıkları söylenebilir. 


\subsection{Katılımcıların Verdikleri Cevapların Bulundukları Gruplar İtibariyle Farklılık Analizleri}

Çalışmada katılımcıların verdikleri cevapların ortalamalarının mezun oldukları ortaöğretim programları ve öğrenim gördükleri sınıflar itibariyle farklılaşıp farklılaşmadığının analizi yapılmıştır. Katılımcıların verdikleri cevapların ortalamalarının mezun oldukları ortaöğretim kurumlarına göre farklılığının analizi bağımsız gruplar t testi (2-tiled) ve bulundukları sınıflara göre farklılığının analizi tek yönlü anova ile yapılmıştır.

Bağımsız gruplar t testinde ve tek yönlü anova analizinde grupların varsyanlarının eşitliğinin test edildiği Levene testinin sonuçlarının değerlendirilmesinde hipotezlerimiz;

$\mathrm{H}_{0}$ : Katılımcıların ilgili değişkene verdikleri cevapların varyansları grupları itibariyle homojendir.

$\mathrm{H}_{1}$ : Katılımcıların ilgili değişkene verdikleri cevapların varyansları grupları itibariyle homojen değildir.

Ticaret lisesi ve diğer program mezunlarının verdikleri cevapların analizinde öncelikle varyansların homojenliği test edilmiştir. Bu amaçla her bir ifade için Levene testi sütununda yer alan p (sig) değerleri incelenmiştir. Bu değerlendirmede ilgili değişken için $\mathrm{p}$ değeri 0,05 'ten küçük olduğunda $\mathrm{H}_{0}$ hipotezi reddedilecektir. $\mathrm{H}_{0}$ hipotezinin rededilmesi durumunda bağımsız gruplar $t$ testi ikinci satırda yer alan $p$ değerine göre kabul veya rededilecektir (Sipahi, Yurtkoru ve Çinko, 2010, s. 123).

Ticaret lisesi ve diğer programlardan mezun katılımcıların bağımsız gruplar t testi (2 tiled) analizlerinde ifadeler için grupların ortalamalarının farklılığının analizinde hipotezlerimiz;

$\mathrm{H}_{0}$ : Ticaret lisesi ve diğer programlardan mezun katılımcıların ilgili değişkene verdikleri cevapların ortalamaları farklılık göstermez.

$\mathrm{H}_{1}$ : Ticaret lisesi ve diğer programlardan mezun katılımcıların ilgili değişkene verdikleri cevapların ortalamaları farklıdır.

Çalışmada katılımcıların öğrenim gördükleri sınıf itibariyle ilgili ifadelere verdikleri cevapların ortalamalarının farklılık gösterip göstermediğini analiz ettiğimiz tek yönlü anova testinde öncelikle Levene testi uygulanmıştır. Bu testte ilgili değişken için p değeri 0,05'ten küçük olduğunda $\mathrm{H}_{0}$ hipotezi reddedilerek varyansların homojen olmadığı sonucuna ulaşılmıştır. Böylece bu değiş̧kenler için varyans analizinin temel varsayımının sağlanmadığı kabul edilmiştir.

Katılımcıların bulundukları sınıf itibariyle ifadelere verdikleri cevapların ortalamalarının farklılık gösterip göstermediğinin analizini yaptığımız tek yönlü anova testinin analizinde hipotezlerimiz;

$\mathrm{H}_{0}$ : Katılımcıların ifadelere verdikleri cevapların ortalamaları bulundukları sınıflara göre farkl111k göstermez. 
$\mathrm{H}_{1}$ : Katılımcıların ifadelere verdikleri cevapların ortalamaları bulundukları sinıflara göre farklidır.

\subsection{Katılımcıların Mezun Oldukları Ortaöğretim Programları İtibariyle Genel Durum Fark Analizi}

Katılımcıların \% 57'si muhasebe eğitimi veren ve genel olarak ticaret lisesi olarak sınıflandırabileceğimiz bir ortaöğretim kurumu mezunudur. Tablo 4'te bu tür ortaöğretim programlarından ve diğer türlerdeki programlardan mezun olan katılımcıların genel durumunu araştıran ifadelere ilişkin yaptığımız bağımsız gruplar $t$ testi (2-tiled) sonuçları sunulmuştur.

Tablo 4. Katılımcıların Mezun Oldukları Ortaöğretim Programları İtibariyle Genel Durum Fark Analizi

\begin{tabular}{|c|c|c|c|c|c|c|c|}
\hline $\begin{array}{ll}\text { 1- } & \text { Ticaret Lisesi Mezunu } \\
\text { 2- } & \text { Diğer Programlar Mezunu }\end{array}$ & & $\mathbf{n}$ & Ort. & SS. & Levene & $\mathbf{p}$ & Hipotez \\
\hline \multirow{2}{*}{ A1. Muhasebe meslek mensubu olmayı istiyorum } & 1 & 183 & 3,97 & 1,17 & \multirow{2}{*}{0,063} & \multirow{2}{*}{0,000} & \multirow{2}{*}{$\mathrm{H}_{1}$ Kabul } \\
\hline & 2 & 132 & 3,43 & 1,28 & & & \\
\hline \multirow{2}{*}{ A4. Bu bölüme geldiğime memnunum } & 1 & 183 & 3,44 & 1,22 & \multirow{2}{*}{0,804} & \multirow{2}{*}{0,000} & \multirow{2}{*}{$\mathrm{H}_{1}$ Kabul } \\
\hline & 2 & 131 & 2,93 & 1,31 & & & \\
\hline \multirow{2}{*}{$\begin{array}{l}\text { A6. Gelecek } 10 \text { yılda belge sahibi olmadan bir işyerinde } \\
\text { çalışıyor olacağım }\end{array}$} & 1 & 181 & 2,14 & 1,23 & \multirow{2}{*}{0,924} & \multirow{2}{*}{0,038} & \multirow{2}{*}{$\mathrm{H}_{1}$ Kabul } \\
\hline & 2 & 132 & 2,43 & 1,24 & & & \\
\hline \multirow{2}{*}{$\begin{array}{l}\text { A8. Gelecek } 10 \text { yılda belge sahibi olarak başkasının bürosunda } \\
\text { olacağım }\end{array}$} & 1 & 181 & 2,41 & 1,09 & \multirow{2}{*}{0,234} & \multirow{2}{*}{0,002} & \multirow{2}{*}{$\mathrm{H}_{1}$ Kabul } \\
\hline & 2 & 132 & 2,80 & 1,12 & & & \\
\hline \multirow{2}{*}{$\begin{array}{l}\text { A9. Gelecek } 10 \text { yılda belge sahibi olmadan başkasının } \\
\text { bürosunda olacağım }\end{array}$} & 1 & 182 & 2,04 & 1,10 & \multirow{2}{*}{0,329} & \multirow{2}{*}{0,008} & \multirow{2}{*}{$\mathrm{H}_{1}$ Kabul } \\
\hline & 2 & 130 & 2,39 & 1,16 & & & \\
\hline \multirow{2}{*}{ A12. Gelecek 10 yılda muhasebe hayatımda olmayacak } & 1 & 182 & 1,91 & 1,18 & \multirow{2}{*}{0,060} & \multirow{2}{*}{0,000} & \multirow{2}{*}{$\mathrm{H}_{1}$ Kabul } \\
\hline & 2 & 132 & 2,57 & 1,33 & & & \\
\hline
\end{tabular}

Yapılan analizde değişkenlerin tamamı için Levene testi $\mathrm{p}$ değerleri 0,05 'ten büyük olduğundan $\mathrm{H}_{0}$ kabul edilerek varyansların homojen olduğu sonucuna ulaşılmıştır. Böylece, yukarıda açıklandığı gibi, bağımsız gruplar $\mathrm{t}$ testi birinci satırında yer alan sonuçlara göre $\mathrm{A} 1$, $\mathrm{A} 4, \mathrm{~A} 6, \mathrm{~A} 8, \mathrm{~A} 9$ ve $\mathrm{A} 12$ değişkenleri için $\mathrm{H}_{1}$ hipotezi kabul edilmiş ve gruplar arasında istatistiki olarak anlamlı farklılık tespit edilmiştir. A1 ve A4 numaralı ifadelerde ticaret lisesi mezunlarının ortalama değerleri daha yüksektir. A1 ifadesine her iki grup da katılım yönünde görüş belirtmişlerdir. A4 değişkenine ticaret lisesi mezunları katılırken, diğer programlardan mezun olanlar kararsız tutum belirtmişlerdir. Diğer taraftan A6, A8, A9 ve A12 ifadelerinde ise en yüksek ortalamalar diğer programlardan mezun olan katılımcılardan elde edilmiştir. A6 ve A12 ifadelerinde her iki grup da katılım, A8 ve A9 değişkenlerinde ise ticaret lisesi mezunları katılım, diğer programlar mezunları kararsızlık yönünde tutum belirtmişlerdir. Bağımsız gruplar $t$ testi sonuçlarına göre $\mathrm{A} 2, \mathrm{~A} 3, \mathrm{~A} 5, \mathrm{~A} 7, \mathrm{~A} 10, \mathrm{~A} 11$ ve $\mathrm{A} 13$ değişkenleri için $\mathrm{H}_{0}$ hipotezi kabul edilmiştir. Böylece bu ifadelerde grupların ortalamaları arasında istatistiki olarak anlamlı fark olmadığı sonucuna ulaşılmıştır.

Elde edilen sonuçlara göre katılımcıların muhasebe meslek mensupluğunun zor olduğu, buna rağmen mezuniyet sonrası stajlarını hemen başlatacakları, gelecek 10 yılda belge sahibi olarak kendi büroları veya başka bir işyerinde çalışma konusunda katılım yönünde anlayış birliği olduğu görülmektedir. Diğer taraftan katılımcılar arasında gelecek 10 
yılda bağımsız denetçilik, müfettişlik benzeri devlet memurluğu ve öğretmenlik / akademisyenlik konusunda kararsızlık yönünde anlayış birliği vardır.

\subsection{Katılımcıların Sınıfları İtibariyle Genel Durum Fark Analizi}

Çalışmada katılımcıların genel durumunu araştırdığımız ifadelere verilen cevapların ortalamalarının bulundukları sınıflar itibariyle farklılığının analizi tek yönlü anova testi ile yapılmıştır. Elde edilen sonuçlar Tablo 5 'te sunulmuştur.

Tablo 5. Katılımcıların Sınıfları İtibariyle Genel Durum Fark Analizi

\begin{tabular}{cccccccc}
\hline & Sinıf & N & Ort. & SS. & Levene & p & Hipotez \\
\hline & 1 & 91 & 3,27 & 1,27 & & & \\
A3 Muhasebe meslek elemanı olmak zor bir iş & 2 & 63 & 3,65 & 1,22 & & & \\
& 3 & 68 & 3,56 & 1,34 & 0,107 & 0,004 & $\mathrm{H}_{1}$ \\
Kabul
\end{tabular}

Analizde uygulanan Levene testinin sonucunda A1, A2 ve A12 numaralı ifadeler dışındaki tüm ifadeler için grupların varyansları (değerleri 0,05 'den büyük olduğu için) homojendir ve varyans analizinin temel varsayımı sağlanmıştır. Analiz sonuçlarına göre A4, A5, A6, A7, A8, A9, A10, A11 ve A13 ifadeler için (p değerleri 0,05'ten büyük olduğundan) $\mathrm{H}_{0}$ hipotezi kabul edilmiş ve katılımcıların genel durum ve tutumlarıyla ilgili değişkenlere verdikleri cevapların ortalamalarının bulundukları sınıflara göre farklılık göstermediği görülmüştür. Varsyans analizinin temel varsayımını sağlayan ve $\mathrm{H}_{1}$ hipotezi kabul edilen A3 ifadesinde gruplar arasında istatistiki olarak anlamlı fark olduğu görülmektedir. Bu ifadede en yüksek ortalama 3,94 ile dördüncü, en düşük ortalama ise 3,27 ile birinci sınıfta öğrenim gören katılımcılardan elde edilmiştir.

\subsection{Etik İlkeler}

Çalışmanın bu bölümümde katılımcıların TÜRMOB etik yönetmeliği doğrultusunda hazırlanan ve genel etik değerlendirmeler, dürüstlük, tarafsızlık, mesleki yeterlilik ve özen, gizlilik ve mesleki davranış olarak gruplandırdığımız ifadelere verdikleri cevapların analizleri yapılmıştır.

\subsubsection{Genel Etik Değerlendirmeler}

Katılımcıların genel etik değerlendirmeler olarak sınıflandırdığımız sekiz adet ifadeye verdikleri cevapların ortalamaları ve standart sapmaları Tablo 6'da sunulmuştur. Elde edilen sonuçlara göre, B39 ifadesine verilen cevapların ortalaması kesinlikle katılıyorum; B1, B2, B3 ve B31 ifadelerine verilen cevapların ortalamaları katılıyorum şeklinde ortaya çıkmıştır. Diğer taraftan B4, B5 ve B30 ifadelerine verilen cevapların ortalamaları ise kararsızlık şeklinde bulunmuştur. 
Tablo 6. Genel Etik Değerlendirmeler Ortalama ve Standart Sapmaları

\begin{tabular}{lcc}
\hline & Ort. & SS \\
\hline B1. Muhasebe meslek mensupları etik kuralları mutlaka benimsemelidir. & 4,05 & 1,15 \\
\hline B2. Yasaların yetersiz kaldı̆̆ı durumlarda meslek mensupları meslek etiğine bağlı kalmalıdırlar. & 3,99 & 1,05 \\
\hline B3. Meslek mensuplarının aylık net geliri arttıkça etiğe verilen önem artmaktadır. & 3,46 & 1,23 \\
\hline B4. Meslek mensupları yasal boşlukları mükelleflerin lehine yorumlamalıdır. & 3,20 & 1,15 \\
\hline B5. Meslek mensuplarına etik kurallara uyulması konusunda baskı yapılıyor & 3,00 & 1,12 \\
\hline $\begin{array}{l}\text { B30. Meslek mensuplarının alacakları ücretlerin Birlik tarafından belirlenmesi ve bu tarifenin altında } \\
\text { ücret kabul edilememesi doğru değildir. }\end{array}$ & 3,37 & 1,30 \\
\hline $\begin{array}{l}\text { B31. Yasal olarak izin verilmediği sürece bağımsızı çalışan meslek mensubu, müşterisine ait para veya } \\
\text { diğer varlıkları, emanet olarak alamaz. }\end{array}$ & 3,81 & 1,11 \\
\hline B39. Dürüstlük, güvenilirlik ve tarafsız olma şartı mesleğin temelini oluşturur & 4,32 & 0,99 \\
\hline
\end{tabular}

$\mathrm{Bu}$ çalışmada, B4 numaralı ifadede yer alan ve katılımcıların kararsız olduğu yasal boşlukların mükellef lehine yorumlaması hususunda, Aymankuy ve Sarığlan (2005) katılımcıların çoğunluğunun yasal boşlukları mükellef lehine yorumladıklarını raporlamışladır. Yalçın (2011) çalışmasında meslek mensuplarından alınan cevapların ortalamalarıyla bu çalışmada elde edilen sonuçlar karşılaştırıldığında B3, B4 ve B30 numaralı ifadelerde öğrencilerden; diğer ifadelerde ise meslek mensuplarından daha yüksek ortalamalar elde edildiği görülmektedir. Buna göre meslek mensuplarının etik ilkeler konusunda daha hassas ve baskı altında oldukları, öğrencilerin yasal boşlukların mükellef lehine yorumlanması ile ücret tarifesinin belirlenmesi ve uygulanmasında Birliğin yetkisi konusunda hassasiyetlerinin daha az olduğu ve gelir seviyesi yükseldikçe daha etik davranabileceklerini düşündüklerini söylemek mümkündür.

\subsection{Katılımeların Verdikleri Cevapların Bulundukları Gruplar İtibariyle Fark Analizleri}

Bu bölümde katılımcıların mesleki etik konusunda genel tutumlarının analiz edildiği ifadelere verdikleri cevapların ortalamalarının mezun oldukları ortaöğretim kurumları ve öğrenim gördükleri sınıflar itibariyle farklılığının analizi yapılmıştır.

\subsection{Katılımcıların Mezun Oldukları Ortaöğretim Programları İtibariyle Genel Etik Değerlendirmeler Fark Analizi}

Ticaret lisesi ve diğer programlardan mezun olanlardan oluşan katılımcı gruplarının genel etik değerlendirmeler olarak sınıflandırdı̆̆ımız değişkenlere verdikleri cevapların farklılı̆ııın analizi bağımsız gruplar $\mathrm{t}$ testi (2-tiled) ile yapılmıştır. Genel etik değerlendirmeler olarak sınıflandırdığımız ifadelerin Levene testi sonuçlarına göre B2 ifadesi dışındaki tüm değişkenler için $\mathrm{H}_{0}$ hipotezi kabul edilmiş ve varyansların eşit olduğu sonucuna ulaşılmıştır. Bu yüzden $\mathrm{B} 2$ değiş̧eni için bağımsız gruplar $\mathrm{t}$ testi ikinci satırında, diğerleri için ise birinci satırında yer alan sonuçlara göre ifadelerin tamamı için $\mathrm{H}_{0}$ hipotezi kabul edilmiş ve gruplar arasında istatistiki olarak anlamlı fark olmadığı sonucuna ulaşılmıştır.

Elde edilen sonuçlar doğrultusunda katılımcı gruplar B39 ifadesinde kesinlikle katılma; B1, B2, B3 ve B31 ifadelerinde katılım; B4 ve B5 ifadelerinde ise kararsizlık konusunda mutabık olmuşlardır. Diğer taraftan B30 ifadesinde grupların verdikleri cevapların ortalamaları arasında istatistiki olarak anlamlı fark ortaya çıkmamasına rağmen, bu değişkene ticaret lisesi mezunlarının verdiği cevapların ortalaması kararsızlık, diğer programlardan 
mezun olanların verdikleri cevapların ortalaması ise katılım yönünde ortaya çıkmıştır. Ayrıca genel etik değerlendirmeler sınıfındaki ifadelerde gruplar arasında istatistiki olarak anlamlı fark bulunmamış olsa da, yüksek ortalamalar A1, A2 ve A31 değişkenlerinde ticaret lisesi mezunlarından, A3, A4, A5, A30 ve A39 değişkenlerinde ise diğer programlardan mezun olanlardan elde edilmiştir.

Sonuç olarak katılımcılar dürüstlük, güvenilirlik ve tarafsızlığın mesleğin temellerini oluşturduğu konusuna kesinlikle katılmaktadırlar. Katılımcılar yasalar yetersiz kalsa bile meslek etiğine bağlı kalınması, mükelleflerden emanet alınmaması, meslek mensubunun geliri arttıkça etiğin ön plana çıktığı ve Birliğin tarifeleri belirlemesi ve tarifenin altında ücret kabul edilememesinin yanlış olduğu konularında katılım yönünde mutabık kalmışlardır. Diğer taraftan katılımcılar yasal boşlukların mükellef lehine yorumlanması ve etik hususunda baskı yapıldığı konularında ise kararsızlık yönünde tutum belirtmişlerdir.

\subsection{Katılımcıların Sınıfları İtibariyle Genel Etik Değerlendirmeler Fark Analizi}

Katılımcıların genel etik değerlendirmeler olarak sınıflandırdığımız sekiz adet ifadeye verdikleri cevapların ortalamalarının bulundukları sınıflar itibariyle farklılığının analizi tek yönlü anova ile yapılmıştır. Analizde uygulanan Levene testinin sonucunda B1 ve B2 numaralı ifadeler dışındaki tüm ifadeler için grupların varyansları (değerleri 0,05'den büyük olduğu için) homojendir ve varyans analizinin temel varsayımı sağlanmıştır. Varyans analizinin temel varsayımını sağlayan tüm ifadelerde ( $p$ değerleri 0,05 'ten büyük olduğundan) $\mathrm{H}_{0}$ hipotezi kabul edilmiş ve katılımcıların genel etik değerlendirmeler sınıfındaki tüm değişkenlere verdikleri cevapların ortalamalarının bulundukları sınıflara göre farklılık göstermediği görülmüştür. Diğer taraftan Kurnaz ve Gümüş (2010) öğrencilerin etik algılarının bulundukları sınıflar itibariyle farklılaştığını raporlamıştır.

\subsubsection{Dürüstlük}

Katılımcıların dürüstlük olarak gruplandırdığımız altı adet ifadeye verdikleri cevapların ortalamaları ve standart sapmaları Tablo 7'de sunulmuştur. Elde edilen sonuçlara göre, B38 ifadesine verilen cevapların ortalaması kesinlikle katılıyorum; B12, B17, B28 ve B36 ifadelerine verilen cevapların ortalamaları ise katılıyorum şeklinde ortaya çıkmıştır. Ancak B18 ifadesine verilen cevapların ortalaması kararsızlık şeklinde bulunmuştur. Bu çalışmada dürüstlük konusundaki ifadelerde öğrencilerden elde edilen ortalamaların tamamı Yalçın (2011) çalışmasında elde edilen ortalamalardan düşüktür. Yalçın (2011) çalışmasında meslek mensupları B18 ve B28 numaralı ifadelere katılım, diğerlerine ise tamamen katılım şeklinde tutum belirtmişlerdir. 
Tablo 7. Dürüstlük Ortalama ve Standart Sapmaları

\begin{tabular}{lcc}
\hline & Ort. & SS. \\
\hline B12. Meslek mensubu daha önce yaptığı bir işlemin hatalı olduğunu anladığında onu düzeltmelidir. & 4,19 & 1,11 \\
\hline B17. Meslek mensubu adil davranmalı ve açık sözlü olmalıdır. & 4,16 & 1,03 \\
\hline $\begin{array}{l}\text { B18. Meslek mensubu herhangi bir bilginin önemli bir hata ya da yanıltıcı biçimde hazırlanmış veya } \\
\text { gizlenmiş ifadeler içerdiğini düşünüyorsa, bu tür bilgiyi veya bu bilgiyle hazıllanmış bir rapor, haber } \\
\text { veya sonucu dikkate almamalıdır. }\end{array}$ & 3,35 & 1,29 \\
\hline $\begin{array}{l}\text { B28. Meslek mensubu bir sözleşme teklifiyle karşılaştığında mevcut meslek mensubuyla müşterinin işleri } \\
\text { hakkında tümüyle ve özgürce konuşmalıdır. }\end{array}$ & 3,94 & 1,09 \\
\hline $\begin{array}{l}\text { B36. Meslek mensupları, işletme sahip ve yöneticilerine, isabetli karar alabilmeleri için doğru ve } \\
\text { güvenilir bilgiler sağlarlar. }\end{array}$ & 4,18 & 1,02 \\
\hline \begin{tabular}{l} 
B38. Meslek mensupları; mesleği yaparken toplum ve devlete karşı sorumluluk taşırlar. \\
\hline
\end{tabular} & 4,23 & 1,05 \\
\hline
\end{tabular}

Sonuç olarak öğrenciler devlete karşı sorumluluğu ön plana çıkartırken, yanıltıcı bilgi ve bunlarla hazırlanmış raporları dikkate almama konusunda kararsızdırlar. Yalçın (2011)'e göre meslek mensupları bu ifadede katılım yönünde tutum belirtmişlerdir.

\subsection{Katılımeların Verdikleri Cevapların Bulundukları Gruplar İtibariyle Fark Analizleri}

Çalışmanın bu bölümünde dürüstlük başlığı altında topladığımız değişkenlere verilen cevapların ortalamalarının katılımcıların mezun oldukları ortaöğretim kurumları ve bulundukları sınıflar itibariyle farklılaşıp farklılaşmadığının analizi yapılmıştır.

\subsection{Katılımcıların Mezun Oldukları Ortaöğretim Programları İtibariyle Dürüstlük Fark Analizi}

Ticaret lisesi ve diğer programlar mezunu grupların dürüstlük olarak sınıflandırdı̆̆ımız değişkenlere verdikleri cevapların ortalamalarının fark analizi bağımsız grup t testi (2-tiled) ile yapılmıştır. Elde edilen sonuçlar Tablo 8'de sunulmuştur. Ticaret lisesi ve diğer programlardan mezun olan öğrencilerden oluşan katılımcı gruplarının dürüstlük olarak sınıflandırdığımız ifadelere verdikleri cevapların Levene testi sonuçlarına göre B17 numaralı ifade dışındaki tüm değişkenler için $\mathrm{H}_{0}$ hipotezi kabul edilmiş ve varyansların eşit olduğu sonucuna ulaşılmıştır. Bu yüzden B17 ifadesi için bağımsız gruplar t testi ikinci satırında, diğerleri için ise birinci satırında yer alan sonuçlarına göre değişkenlerin analizi yapılmıştır. Buna göre B18, B28, B36 ve B38 numaralı ifadeler için $\mathrm{H}_{0}$ hipotezi kabul edilmiş ve gruplar arasında istatistiki olarak anlamlı fark olmadığ sonucuna ulaşılmıştır. $\mathrm{H}_{1}$ hipotezi kabul edilen B12 ve B17 ifadelerinden elde edilen ortalamalara göre ticaret lisesi mezunları kesinlikle katıllyorum, diğer programlardan mezun olanlar ise katıliyorum şeklinde tutum belirtmişlerdir. 
Tablo 8. Katılımcıların Mezun Oldukları Ortaöğretim Programları İtibariyle Dürüstlük Fark Analizi

\begin{tabular}{|c|c|c|c|c|c|c|c|}
\hline $\begin{array}{ll}\text { 1- } & \text { Ticaret Lisesi Mezunu } \\
\text { 2- } & \text { Diğer Programlar Mezunu }\end{array}$ & & $\mathbf{N}$ & Ort. & SS. & Levene & $\mathbf{P}$ & Hipotez \\
\hline \multirow{2}{*}{$\begin{array}{l}\text { B12. Meslek mensubu daha önce yaptığı bir işlemin } \\
\text { hatalı olduğunu anladığında onu düzeltmelidir. }\end{array}$} & 1 & 183 & 4,31 & 1,09 & \multirow{2}{*}{0,963} & \multirow{2}{*}{0,046} & \multirow{2}{*}{$\mathrm{H}_{1}$ Kabul } \\
\hline & 2 & 132 & 4,06 & 1,10 & & & \\
\hline \multirow{2}{*}{ B17. Meslek mensubu adil davranmalı ve açık sözlü olmalıdır. } & 1 & 183 & 4,34 & 0,89 & \multirow{2}{*}{0,003} & \multirow{2}{*}{0,001} & \multirow{2}{*}{$\mathrm{H}_{1} \mathrm{Kabul}$} \\
\hline & 2 & 131 & 3,95 & 1,15 & & & \\
\hline
\end{tabular}

Diğer taraftan katılımcılar B18 ifadesinde kararsızlık ve B28 ifadesinde katılıyorum şeklinde tutum belirtmişlerdir. Katılımcı gruplar arasında istatistiki olarak anlamlı bir fark bulunmamış olmasına rağmen, B36 ve B38 ifadelerinde ticaret lisesi mezunlarının cevapları kesinlikle katılıyorum, diğer programlardan mezun olanların cevapları ise katılıyorum şeklinde ortaya çıkmıştır. Genel bir değerlendirmede ile ticaret lisesinden mezun olan katılımcıların bu grupta yer alan ifadelere diğer programlardan mezun olanlara göre daha yüksek ortalamalarda katılım belirttiği söylenebilir.

\subsection{Katılımcıların Sınıfları İtibariyle Dürüstlük Fark Analizi}

Katılımcıların dürüstlük olarak sınıflandırdığımız altı adet ifadeye verdikleri cevapların ortalamalarının bulundukları sinıflar itibariyle fark analizi tek yönlü anova ile yapılmıştır. Analizde uygulanan Levene testi sonucunda sadece B18 ve B28 numaralı ifadeler için grupların varyansları (değerleri 0,05 'den büyük olduğu için) homojendir. Varyans analizinin temel varsayımını sağlayan her iki ifade için de $\mathrm{H}_{0}$ hipotezi kabul edilmiştir. Böylece ifadelerin hiç birinde gruplar arasında istatistiki olarak anlamlı fark tespit edilememiştir.

\subsubsection{Tarafsızlık}

Katılımcıların tarafsızlık olarak sinıflandırdığımız altı adet ifadeye verdikleri cevapların ortalamaları ve standart sapmaları Tablo 9'da sunulmuştur.

Tablo 9. Tarafsızlık Ortalama ve Standart Sapmaları

\begin{tabular}{lcc}
\hline & Ort. & SS. \\
\hline $\begin{array}{l}\text { B9. Üçüncü kişilerin haksız ve uygunsuz biçimde yaptıkları baskılar meslek mensuplarının meslekî } \\
\text { kararlarını etkilememelidir. }\end{array}$ & 4,00 & 1,18 \\
\hline B10. Meslek mensubu sunduğu bilgilerde yanlı veya önyargılı davranmamalıdır. & 4,20 & 1,06 \\
\hline B13. Meslek mensubunun karşılaştı̆̆ her türlü gerçek veya hissedilen tehdit onun tarafsızlığına gölge & 4,06 & 1,13 \\
\hline B14. Meslek mensubunun kendisinin veya yakın ailesinden bir üyenin finansal veya diğer çıkarları & 3,55 & 1,20 \\
\hline B29. Meslek mensubunun çıkar çatışması içinde olan müşterilere hizmet sunması tarafsılık veya & 3,69 & 1,13 \\
\hline B35. Meslek mensupları bağımsızlıklarına gölge düşürecek ilişkilerden ve davranışlardan & 4,13 & 1,07 \\
\hline
\end{tabular}

Elde edilen sonuçlara göre B10 ifadesine verilen cevapların ortalaması kesinlikle katılıyorum şeklindedir. Diğer ifadelere ise katılım yönünde tutum belirtmişlerdir. Bu ifadelere verilen cevapların ortalamaları Yalçın (2011) çalışmasında elde edilen ortalamalara göre daha düşüktür. Böylece meslek mensuplarının tarafsızlık konusunda daha hassas olduğu söylenebilir. 


\subsection{Katılımeların Verdikleri Cevapların Bulundukları Gruplar İtibariyle Fark Analizleri}

Çalışmanın bu bölümünde katılımcıların tarafsızlık olarak sınıflandırdığımız ifadelere verdiklerin cevapların ortalamalarının mezun oldukları ortaöğretim kurumu ve eğitim gördükleri sınıflara göre farklı olup olmadığının analizi yapılmıştır.

\subsection{Katılımcıların Mezun Oldukları Ortaöğretim Programları İtibariyle Tarafsızlık Fark Analizi}

Çalışmada ticaret lisesi ve diğer programlar mezunu grupların tarafsızlık olarak sınıflandırdığımız değişkenlere verdikleri cevapların ortalamalarının fark analizi yapılmıştır. Buna göre ifadelerin tamamı için Levene testi $\mathrm{p}$ değerleri 0,05 'ten büyük olduğundan $\mathrm{H}_{0}$ kabul edilerek varyanslarının eşit olduğu sonucuna ulaşılmıştır. Bağımsız gruplar t testi (2tiled) analizine göre, değişkenlerin tamamı için $\mathrm{H}_{0}$ hipotezi kabul edilmiştir. Böylece tüm değişkenler için gruplar arasında istatistiki olarak anlamlı fark olmadığı sonucu ortaya çıkmıştır. Gruplar arasında istatistiki olarak anlamlı farklılık bulunmamasına rağmen, B10 ve B35 ifadelerinde ticaret lisesi mezunlarından elde edilen ortalamalar kesinlikle katıliyorum; diğer programlardan mezun olanlardan elde edilen ortalamalar ise katılıyorum şeklindedir.

\subsection{Katılımeların Sınıfları İtibariyle Tarafsızlık Fark Analizi}

Katılımcıların tarafsızlık olarak sınıflandırdığımız altı adet ifadeye verdikleri cevapların ortalamalarının bulundukları sınıflar itibariyle farklılığının analizi tek yönlü anova ile yapılmış ve sonuçlar Tablo 10'da sunulmuştur. Levene testinin sonucunda B10, B13 ve B14 numaralı ifadeler için grupların varyansları homojendir ve varyans analizinin temel varsayımı sağlanmıştır. Bu ifadelerden sadece B10 ve B13 numaralı ifadelerde istatistiki olarak anlamlı fark tespit edilmişsir.

Tablo 10. Katılımcıların Sınıfları İtibariyle Tarafsızlık Fark Analizi

\begin{tabular}{lccccccc}
\hline & Sinıf & $\mathbf{N}$ & Ort. & SS. & Levene & p & Hipotez \\
\hline & 1 & 90 & 3,98 & 1,19 & & & \\
B10. Meslek mensubu sunduğu bilgilerde yanlı veya & 2 & 63 & 4,21 & 0,13 & \multirow{2}{*}{0,064} & 0,039 & $\mathrm{H}_{1}$ \\
Kabul & 3 & 68 & 4,18 & 1,06 & & \\
\hline önyargılı davranmamalıdır. & 4 & 97 & 4,42 & 0,92 & & & \\
& 1 & 91 & 3,76 & 1,23 & & & $\mathrm{H}_{1}$ \\
B13. Meslek mensubunun karşılaştığı her türlü gerçek & 2 & 63 & 4,03 & 1,12 & \multirow{2}{*}{0,129} & 0,014 & Kabul \\
veya hissedilen tehdit onun tarafsızlığına gölge & 3 & 68 & 4,18 & 1,09 & & & \\
düşürmemelidir. & 4 & 97 & 4,27 & 1,03 & & &
\end{tabular}

B10 ifadesinde en yüksek ortalama 4,42 ile dördüncü ve en düşük ortalama 3,98 ile birinci sinıflardan elde edilmiştir. B13 ifadesinde ise en yüksek ortalama 4,27 ile dördüncü ve en düşük ortalama 3,76 ile birinci sınıflarda yer alan öğrencilerden elde edilmiştir. Böylece bu iki ifadede dördüncü sinıflar kesinlikle katıllyorum, birinci sınıflar katılıyorum şeklinde tutum belirtmişlerdir. 


\subsubsection{Mesleki Yeterlilik ve Özen}

Katılımcıların mesleki yeterlilik ve özen olarak sınıflandırdığımız ifadelere verdikleri cevapların ortalamaları ve standart sapmaları Tablo 11'de sunulmuştur. Elde edilen sonuçlara göre, B27 ve B46 ifadelerine verilen cevapların ortalamaları kesinlikle katılıyorum; diğer ifadelere verilen cevapların ortalamaları ise katılıyorum şeklindedir. Çalışmada mesleki yeterlilik ve özen sınıfındaki ifadelere öğrencilerden elde edilen ortalamaların tamamı Yalçın (2011) çalışmasında meslek mensuplarından elde edilen ortalamaların altındadır. Böylece meslek mensuplarının mesleki yeterlilik ve özen grubunda yer alan ifadelere daha duyarlı olduğunu söyleyebiliriz.

Tablo 11. Mesleki Yeterlilik Ve Özen Ortalama ve Standart Sapmaları

\begin{tabular}{lcc}
\hline & Ort. & SS. \\
\hline $\begin{array}{l}\text { B11. Meslek mensubu meslekî faaliyetlerini yerine getirirken teknik ve meslekî standartlara uygun } \\
\text { davranmalıdır. }\end{array}$ & 4,05 & 1,13 \\
\hline B15. Mesleğe giriş için meslekî eğitim, staj ve tecrübe şartlarının aranması gereklidir. & 3,94 & 1,11 \\
\hline B16. Meslekî gelişim gereksinimlerini karşılamak için sürekli kurs ve seminerlere katılmak gereklidir. & 3,62 & 1,12 \\
\hline $\begin{array}{l}\text { B19. Meslek mensubu, kendi otoritesi altında çalışanların da uygun meslekî eğitim almalarını ve gözetim } \\
\text { altında tutulmalarını sağlamalıdır. }\end{array}$ & 4,05 & 1,04 \\
\hline $\begin{array}{l}\text { B25. Meslek mensubu sözleşme yaparken müşterinin yaptı̆̆ı işin özelliği, faaliyetlerinin karmaşıklığı, } \\
\text { sözleşmenin özel şartları, sunulacak hizmetin özelliği, amacı ve yapısı ile ilgili yeterli bir bilgiye sahip } \\
\text { olmalıdır. }\end{array}$ & 4,10 & 1,05 \\
\hline $\begin{array}{l}\text { B26. Meslek mensubu sözleşme yaparken kullanılacak düzenleme veya raporlama usulleri ile ilgili deneyim } \\
\text { sahibi olmalıdır. }\end{array}$ & 4,08 & 1,02 \\
\hline B27. Meslek mensubu gerekli olduğunda uzman görüşlerinden yararlanmalıdır. & 4,20 & 1,02 \\
\hline $\begin{array}{l}\text { B37. Meslek mensupları, ilgili yönetmelikler çerçevesinde ve mesleki eğitimde birbirlerine her türlü bilgiyi } \\
\text { vermek ve aktarmak sorumluluğunu taşırlar. }\end{array}$ & 4,05 & 1,02 \\
\hline $\begin{array}{l}\text { B46. Meslek mensupları kamu yararı uygun davranmayı ilke edinmeli, kamunun güvenine önem vermeli } \\
\text { ve mesleğine yakışır bir uzman gibi davranmalıdır. }\end{array}$ & 4,20 & 1,08 \\
\hline
\end{tabular}

\subsection{Katılımcıların Verdikleri Cevapların Bulundukları Gruplar İtibariyle Fark Analizleri}

Çalışmanın bu bölümünde katılımcıların mesleki yeterlilik ve özen sınıfında yer alan dokuz adet ifadeye verdikleri cevapların mezun oldukları ortaöğretim programı ve öğrenim gördükleri sınıflar itibariyle farklılaşıp farklılaşmadığının analizleri yapılmıştır.

\subsection{Katılımcıların Mezun Oldukları Ortaöğretim Programları İtibariyle Mesleki Yeterlilik ve Özen Fark Analizi}

Ticaret lisesi ve diğer programlardan mezun öğrencilerden oluşan grupların mesleki yeterlilik ve özen olarak sinıflandırdığımız dokuz adet ifadeye verdikleri cevapların ortalamalarının fark analizi Tablo 12'de sunulmuştur. 
Tablo 12. Katılımcıların Mezun Oldukları Ortaöğretim Programları İtibariyle Mesleki Yeterlilik ve Özen Fark Analizi

\begin{tabular}{|c|c|c|c|c|c|c|c|}
\hline $\begin{array}{ll}\text { 1- } & \text { Ticaret Lisesi Mezunu } \\
\text { 2- } & \text { Diğer Programlar Mezunu }\end{array}$ & & $\mathbf{N}$ & Ort. & SS. & Levene & $\mathbf{p}$ & Hipotez \\
\hline \multirow{2}{*}{$\begin{array}{l}\text { B11. Meslek mensubu meslekî faaliyetlerini yerine getirirken teknik ve } \\
\text { meslekî standartlara uygun davranmalıdır. }\end{array}$} & 1 & 183 & 4,17 & 1,09 & \multirow{2}{*}{0,176} & \multirow{2}{*}{0,030} & \multirow{2}{*}{$\mathrm{H}_{1}$ Kabul } \\
\hline & 2 & 132 & 3,89 & 1,19 & & & \\
\hline \multirow{2}{*}{$\begin{array}{l}\text { B19. Meslek mensubu, kendi otoritesi altında çalışanların da uygun } \\
\text { meslekî eğitim almalarını ve gözetim altında tutulmalarını sağlamalıdır. }\end{array}$} & 1 & 183 & 4,14 & 0,14 & \multirow{2}{*}{0,796} & \multirow{2}{*}{0,138} & \multirow{2}{*}{$\mathrm{H}_{1}$ Kabul } \\
\hline & 2 & 132 & 3,96 & 1,06 & & & \\
\hline \multirow{2}{*}{$\begin{array}{l}\text { B26. Meslek mensubu sözleşme yaparken kullanılacak düzenleme veya } \\
\text { raporlama usulleri ile ilgili deneyim sahibi olmalıdır. }\end{array}$} & 1 & 182 & 4,20 & 0,93 & \multirow{2}{*}{0,188} & \multirow{2}{*}{0,048} & \multirow{2}{*}{$\mathrm{H}_{1} \mathrm{Kabul}$} \\
\hline & 2 & 129 & 3,97 & 1,10 & & & \\
\hline
\end{tabular}

Buna göre değişkenlerin tamamı için, Levene testi $\mathrm{p}$ değerleri 0,05 'ten büyük olduğundan, $\mathrm{H}_{0}$ kabul edilmiş ve varyansların eşit olduğu sonucuna ulaşılmıştır. Bağımsız gruplar t testi (2-tiled) sonuçlarına göre B11, B19 ve B26 numaralı değişkenler için $\mathrm{H}_{0}$ hipotezi kabul edilerek gruplar arasında istatistiki olarak anlamlı fark olmadığı sonucuna ulaşılmıştır. $\mathrm{H}_{1}$ hipotezi kabul edilen $\mathrm{B} 11, \mathrm{~B} 19$ ve B26 ifadelerine verilen cevaplardan elde edilen her iki grubun ortalaması da katılıyorum şeklindedir. Bununla birlikte bu değişkenlerde yüksek ortalamalar ticaret lisesi mezunu katılımcılardan elde edilmiştir. Diğer taraftan istatistiki olarak anlamlı fark tespit edilmeyen B25, B27 ve B46 ifadelerinde ticaret lisesi mezunlarından elde edilen ortalamalar kesinlikle katıliyorum; diğer programlardan mezun olanlardan elde edilen ortalamalar katılıyorum şeklindedir.

\subsection{Katılımcıların Sınıfları İtibariyle Mesleki Yeterlilik ve Özen Fark Analizi}

Katılımcıların mesleki yeterlilik ve özen olarak sınıflandırdığımız dokuz adet ifadeye verdikleri cevapların ortalamalarının bulundukları sınıflar itibariyle farklılığının tek yönlü anova ile analizinden elde ettiğimiz sonuçlar Tablo 13'te sunulmuştur. Levene testinin sonucunda B15, B16, B19, B37 ve B46 numaralı ifadeler için grupların varyansları (değerleri 0,05 'den büyük olduğu için) homojendir ve varyans analizinin temel varsayımı sağlanmıştır. $\mathrm{Bu}$ ifadelerden sadece B19 ve B46 numaralı ifadelerde $\mathrm{H}_{1}$ hipotezi kabul edilerek verilen cevapların ortalamalarında gruplar itibariyle istatistiki olarak anlamlı fark olduğu görülmüştür. B19 ifadesinde en yüksek ortalama 4,26 ile üçüncü, en düşük ortalama 3,85 ile birinci sinıflarda bulunan öğrencilerden elde edilmiştir. Diğer taraftan B46 ifadesinde en yüksek ortalama 4,43 ile dördüncü ve en düşük ortalama 4,00 ile birinci sinıflarda yer alan öğrencilerden elde edilmiştir.

Tablo 13. Katılımcıların Sınıfları İtibariyle Mesleki Yeterlilik ve Özen Fark Analizi

\begin{tabular}{|c|c|c|c|c|c|c|c|}
\hline & Sinıf & $\mathbf{N}$ & Ort. & SS. & Levene & $\mathbf{p}$ & Hipotez \\
\hline \multirow{4}{*}{$\begin{array}{l}\text { B19. Meslek mensubu, kendi otoritesi altında çalışanların da uygun } \\
\text { meslekî eğitim almalarını ve gözetim altında tutulmalarını } \\
\text { sağlamalıdır. }\end{array}$} & 1 & 91 & 3,85 & 1,11 & \multirow{4}{*}{0,491} & \multirow{4}{*}{,049 } & \multirow{4}{*}{$\mathrm{H}_{1}$ Kabul } \\
\hline & 2 & 63 & 3,97 & 1,05 & & & \\
\hline & 3 & 68 & 4,26 & 0,80 & & & \\
\hline & 4 & 97 & 4,15 & 1,07 & & & \\
\hline \multirow{4}{*}{$\begin{array}{l}\text { B46. Meslek mensupları kamu yararına uygun davranmayı ilke } \\
\text { edinmeli, kamunun güvenine önem vermeli ve mesleğine yakışır bir } \\
\text { uzman gibi davranmalıdır. }\end{array}$} & 1 & 88 & 4,00 & 1,17 & \multirow{4}{*}{0,204} & \multirow{4}{*}{0,048} & \multirow{4}{*}{$\mathrm{H}_{1}$ Kabul } \\
\hline & 2 & 63 & 4,13 & 1,13 & & & \\
\hline & 3 & 67 & 4,21 & 1,05 & & & \\
\hline & 4 & 97 & 4,43 & 0,93 & & & \\
\hline
\end{tabular}




\subsubsection{Gizlilik}

Katılımcıların tamamının gizlilik olarak sınıflandırdığımız dört adet değişkene verdikleri cevapların ortalamaları ve standart sapmaları Tablo 14'te sunulmuştur. Anket sonuçlarına göre katılımcıların tüm değişkenler için verdikleri cevapların ortalamaları katılıyorum şeklinde ortaya çıkmıştır. Diğer taraftan Yalçın (2011) çalışmasında meslek mensuplarının aynı ifadeler için verdikleri cevapların ortalaması kesinlikle katılıyorum şeklindedir.

Tablo 14. Gizlilik Ortalama ve Standart Sapmaları

\begin{tabular}{lcc}
\hline B7. Aksi yasal olarak belirtilmedikçe görev sırasında elde edilen verilerin başkalarılyla paylaşılmaması gerekir. & Ort. & SS. \\
\hline $\begin{array}{l}\text { B20. Meslek mensubunun meslekî iliş̧kisi sonucu elde edilen gizli bilgiyi kişisel çıkar uğruna ya da üçüncü } \\
\text { kişilerin yararına kullanmaması ya da kullanıyor izlenimi bırakmaması gerekmektedir. }\end{array}$ & 4,13 \\
\hline $\begin{array}{l}\text { B21. Meslek mensubunun gizlilik sorumluluğu müşteri ya da işveren ile ilişkisi sona erdiği zaman bile devam } \\
\text { etmelidir. }\end{array}$ & \multirow{2}{*}{4,14} \\
\hline $\begin{array}{l}\text { B22. Meslek mensubu, kendi kontrolü altında çalışan elemanların ve danışmanlık veya tavsiye hizmeti aldığı } \\
\text { diğer meslek mensuplarının veya üçüncü kişilerin gizlilik ilkesinin gereklerine saygı göstermelerini } \\
\text { sağlamakla yükümlüdür. }\end{array}$ & 4,07 \\
\hline
\end{tabular}

\subsection{Katılımcıların Verdikleri Cevapların Bulundukları Gruplar İtibariyle Fark Analizleri}

Çalışmanın bu bölümünde katılımcıların dört adet ifadeden oluşan gizlilik grubunda yer alan ifadelere verdikleri cevapların mezun oldukları ortaöğretim programı ve öğrenim gördükleri sınıflar itibariyle farklılaşıp farklılaşmadığının analizleri yapılmıştır.

\subsection{Katılımcıların Mezun Oldukları Ortaöğretim Programları İtibariyle Gizlilik Fark Analizi}

Ticaret lisesi ve diğer programlardan mezun grupların gizlilik olarak sınıflandırdığımız ifadelere verdikleri cevapların ortalamalarının fark analizi Tablo 15'de sunulmuştur. Levene testinde değişkenlerin tamamı için, $\mathrm{H}_{0}$ kabul edilerek varyansların eşit olduğu sonucuna ulaşılmıştır. Bağımsız gruplar t testi (2-tiled) analizinde B20 ifadesi için gruplar arasında farklılık tespit edilmemiştir. $\mathrm{H}_{1}$ hipotezi kabul edilen $\mathrm{B} 7, \mathrm{~B} 21$ ve B22 ifadelerinde ticaret lisesi mezunları kesinlikle katılıyorum; diğer program mezunları katılıyorum şeklinde tutum belirtmişlerdir. 
Tablo 15. Katılımcıların Mezun Oldukları Ortaöğretim Programları İtibariyle Gizlilik Fark Analizi

\begin{tabular}{|c|c|c|c|c|c|c|c|}
\hline $\begin{array}{ll}\text { 1- } & \text { Ticaret Lisesi Mezunu } \\
\text { 2- } & \text { Diğer Programlar Mezunu }\end{array}$ & & $\mathbf{N}$ & Ort. & SS. & Levene & $\mathbf{p}$ & Hipotez \\
\hline \multirow{2}{*}{$\begin{array}{l}\text { B7. Aksi yasal olarak belirtilmedikçe görev sırasında elde } \\
\text { edilen verilerin başkalarıyla paylaşılmaması gerekir. }\end{array}$} & 1 & 183 & 4,25 & 1,04 & \multirow{2}{*}{0,201} & \multirow{2}{*}{0,012} & \multirow{2}{*}{$\mathrm{H}_{1} \mathrm{Kabul}$} \\
\hline & 2 & 132 & 3,92 & 1,196 & & & \\
\hline \multirow{2}{*}{$\begin{array}{l}\text { B21. Meslek mensubunun gizlilik sorumluluğu müşteri ya da } \\
\text { işveren ile ilişkisi sona erdiği zaman bile devam etmelidir. }\end{array}$} & 1 & 182 & 4,28 & 1,47 & \multirow{2}{*}{0,136} & \multirow{2}{*}{0,009} & \multirow{2}{*}{$\mathrm{H}_{1}$ Kabul } \\
\hline & 2 & 129 & 3,96 & 1,13 & & & \\
\hline \multirow{2}{*}{$\begin{array}{l}\text { B22. Meslek mensubu, kendi kontrolü altında çalışan } \\
\text { elemanların ve danışmanlık veya tavsiye hizmeti aldığı diğer } \\
\text { meslek mensuplarının veya üçüncü kişilerin gizlilik ilkesinin } \\
\text { gereklerine saygı göstermelerini sağlamakla yükümlüdür. }\end{array}$} & 1 & 182 & 4,26 & 1,04 & \multirow[b]{2}{*}{0,978} & \multirow[b]{2}{*}{0,009} & \multirow[b]{2}{*}{$\mathrm{H}_{1}$ Kabul } \\
\hline & 2 & 129 & 3,94 & 1,12 & & & \\
\hline
\end{tabular}

\subsection{Katılımcıların Sınıfları İtibariyle Gizlilik Fark Analizi}

Çalışmada katılımcıların gizlilik olarak isimlendirdiğimiz dört adet ifadeye verdikleri cevapların ortalamalarının bulundukları sınıflar itibariyle fark analizi tek yönlü anova ile yapılmıştır. Levene testine göre sadece B20 ifadesinde varyans analizinin temel varsayımı sağlanmıştır. $\mathrm{Bu}$ değişsen için $\mathrm{H}_{0}$ hipotezi kabul edilmiş ve gruplar itibariyle anlamlı fark olmadığ görülmüş̧tür.

\subsubsection{Mesleki Davranış}

Katılımcıların tamamının mesleki davranış olarak sınıflandırdığımız 13 adet ifadeye verdikleri cevapların ortalamaları ve standart sapmaları Tablo 16'da sunulmuştur.

Tablo 16. Mesleki Davranış Ortalama ve Standart Sapmaları

\begin{tabular}{|c|c|c|}
\hline & Ort. & SS. \\
\hline B6. Meslek mensupları görevlerini icra ederken yasa ve yönetmeliklere uymalıdır. & 4,13 & 1,07 \\
\hline B8. Meslek mensubu mesleğin itibarını zedeleyecek her türlü davranıştan kaçınmalıdır. & 4,27 & 1,08 \\
\hline B23. Meslek mensubu değeri önemsiz olanlar hariç, bir müşteriden hediye veya ayrıcalıklı hizmet almamalıdır. & 3,77 & 1,18 \\
\hline $\begin{array}{l}\text { B24. Meslek mensubu yeni bir müşteriyi kabul etmeden önce, bu tür bir iş kabulünün temel etik ilkelere yönelik } \\
\text { bir tehdit yaratmayacağından emin olmalıdır. }\end{array}$ & 4,13 & 0,99 \\
\hline $\begin{array}{l}\text { B32. Meslek mensupları, başka bir meslek mensubu ile mesleki sözleşmesi devam eden gerçek ve tüzel kişilere } \\
\text { mesleki hizmet vermeye girişemezler. }\end{array}$ & 3,66 & 1,14 \\
\hline B33. Meslek mensupları haksız rekabete neden olacak davranışlardan kaçınmalıdırlar. & 4,09 & 1,09 \\
\hline $\begin{array}{l}\text { B34. Meslek mensupları ücret ve eleman temini gibi konularda birbirlerine zarar verecek davranışlarda } \\
\text { bulunamazlar. }\end{array}$ & 4,07 & 1,04 \\
\hline B40. Meslek mensubu reklâm yoluyla haksız rekabet yapamaz. & 3,85 & 1,20 \\
\hline B41. Meslek mensubu ücret ve diğer mali nitelikteki uygulamalar ile haksız rekabet yapamaz. & 3,92 & 1,14 \\
\hline B42. Meslek mensupları kendi aralarında ve iş sahipleriyle ilişkilerde haksız rekabet yapılmamalıdır. & 4,07 & 1,06 \\
\hline $\begin{array}{l}\text { B43. Meslek mensubunun mesleki ruhsatını kiralanması veya çeşitli menfaatler sağlayarak meslek mensubu } \\
\text { olmayan kişilere faaliyette bulunma imkânı sağlaması doğru değildir. }\end{array}$ & 3,95 & 1,13 \\
\hline $\begin{array}{l}\text { B44. Meslek mensubunun asgari ücret tarifesinin altında ücret talep etmesi veya ücretsiz hizmet vermesi doğru } \\
\text { değildir. }\end{array}$ & 4,05 & 1,07 \\
\hline $\begin{array}{l}\text { B45. Meslek mensubunun başka bir meslek mensubuna olan ücret borcunu ödememiş iş sahibine hizmet vermesi } \\
\text { doğru değildir. }\end{array}$ & 3,84 & 1,11 \\
\hline
\end{tabular}

Elde edilen sonuçlara göre, B8 ifadesine verilen cevapların ortalaması kesinlikle katılıyorum şeklindedir. Diğer ifadelere verilen cevapların ortalamaları, bazıları kesinlikle 
katılıyorum seçeneğine yakın olmakla birlikte, katılıyorum şeklinde ortaya çıkmıştır. Yalçın (2011) çalışmasında ise meslek mensupları B23 ve B45 numaralı ifadelere katılıyorum, diğerlerine ise kesinlikle katılıyorum şeklinde tutum belirtmişlerdir.

\subsection{Katılımcıların Verdikleri Cevapların Bulundukları Gruplar İtibariyle Fark Analizleri}

Çalışmada katılımcıların mesleki davranış olarak gruplandırdığımız ifadelere verdikleri cevapların mezun oldukları ortaöğretim kurumları ve halen eğitim gördükleri sınıflar itibariyle farklılaşıp farklılaşmadığının analizi yapılmıştır.

\subsection{Katılımcıların Mezun Oldukları Ortaöğretim Programları İtibariyle Mesleki Davranış Fark Analizi}

Ticaret lisesi ve diğer programlardan mezun grupların mesleki davranış olarak sınıflandırdığımız ifadelere verdikleri cevapların ortalamalarının fark analizi Tablo 17'de sunulmuştur. Levene testinde B8 ifadesi hariç değişkenlerin tamamının için varyansların eşit olduğu sonucuna ulaşılmıştır. Bu yüzden $\mathrm{B} 8$ ifadesi için bağımsız gruplar $\mathrm{t}$ testi ikinci satırında, diğerleri için ise birinci satırında yer alan sonuçlara göre değişkenlerin analizi yapılmıştır. Analizde B6, B8 ve B33 ifadelerinde gruplar arasında anlamlı fark bulunmuştur. Her üç değişkende de yüksek ortalamalar, kesinlikle katıllyorum şeklinde ve ticaret lisesi mezunlarından elde edilmiştir. $\mathrm{Bu}$ değişkenler için diğer programlardan mezun olan öğrencilerden elde cevapların ortalamaları ise katılıyorum şeklindedir.

Tablo 17. Katılımcıların Mezun Oldukları Ortaöğretim Programları İtibariyle Mesleki Davranış Fark Analizi

\begin{tabular}{|c|c|c|c|c|c|c|c|}
\hline $\begin{array}{ll}\text { 1- } & \text { Ticaret Lisesi Mezunu } \\
\text { 2- } & \text { Diğer Programlar Mezunu }\end{array}$ & & $\mathbf{N}$ & Ort. & SS. & Levene & $\mathbf{p}$ & Hipotez \\
\hline \multirow{2}{*}{$\begin{array}{l}\text { B6. Meslek mensupları görevlerini icra ederken yasa ve } \\
\text { yönetmeliklere uymalıdır. }\end{array}$} & 1 & 183 & 4,26 & 1,93 & \multirow{2}{*}{0,804} & \multirow{2}{*}{0,009} & \multirow{2}{*}{$\mathrm{H}_{1} \mathrm{Kabul}$} \\
\hline & 2 & 131 & 3,95 & 1,12 & & & \\
\hline \multirow{2}{*}{$\begin{array}{l}\text { B8. Meslek mensubu mesleğin itibarını zedeleyecek her türlü } \\
\text { davranıştan kaçınmalıdır. }\end{array}$} & 1 & 182 & 4,43 & 0,97 & \multirow{2}{*}{0,035} & \multirow{2}{*}{0,005} & \multirow{2}{*}{$\mathrm{H}_{1} \mathrm{Kabul}$} \\
\hline & 2 & 131 & 4,07 & 1,18 & & & \\
\hline \multirow{2}{*}{$\begin{array}{l}\text { B33. Meslek mensupları haksız rekabete neden olacak davranışlardan } \\
\text { kaçınmalıdırlar. }\end{array}$} & 1 & 182 & 4,22 & 1,02 & \multirow{2}{*}{0,603} & \multirow{2}{*}{0,037} & \multirow{2}{*}{$\mathrm{H}_{1} \mathrm{Kabul}$} \\
\hline & 2 & 129 & 3,96 & 1,13 & & & \\
\hline
\end{tabular}

\subsection{Katılımcıların Sınıfları İtibariyle Mesleki Davranış Fark Analizi}

Katılımcıların mesleki davranış olarak isimlendirdiğimiz 13 adet ifadeye verdikleri cevapların ortalamalarının öğrenim gördükleri sınıflar itibariyle farklılığının tek yönlü anova ile analizinden elde ettiğimiz sonuçlar Tablo 18'de sunulmuştur.

Tablo 18. Katılımcıların Sınıfları İtibariyle Mesleki Davranış Fark Analizi

\begin{tabular}{llllllll}
\hline Sinıf & & N & Ort. & SS. & Levene & p & Hipotez \\
\hline & 1 & 91 & 3,87 & 1,19 & & & \\
B6. Meslek mensupları görevlerini icra ederken yasa ve & 2 & 63 & 4,11 & 1,06 & 0,183 & 0,030 & $\mathrm{H}_{1}$ Kabul \\
yönetmeliklere uymalıdır. & 3 & 67 & 4,21 & 0,93 & & & \\
& 4 & 97 & 4,32 & 1,57 & & & \\
\hline
\end{tabular}


Levene testi sonuçlarına göre B8 ve B33 numaralı ifadeler dışındaki tüm ifadeler için grupların varyansları homojendir ve varyans analizinin temel varsayımı sağlanmıştır. Bunlardan sadece $\mathrm{B} 6$ için $\mathrm{H}_{1}$ hipotezi kabul edilerek verilen cevapların ortalamalarında gruplar itibariyle istatistiki olarak anlamlı fark olduğu görülmüş̧ür. Bu ifadede en yüksek ortalama 4,32 ile dördüncü ve en düşük ortalama 3,87 ile birinci sınıflardan elde edilmiştir. Diğer ifadelerin tamamı için $\mathrm{H}_{0}$ hipotezi kabul edilmiş ve katılımcıların ilgili ifadelere verdikleri cevapların bulundukları sınıflara göre farklılık göstermediği görülmüşsür.

\section{SONUC}

$\mathrm{Bu}$ çalışmada yoğun olarak muhasebe eğitimi verilen Kütahya Dumlupınar Üniversitesi Uygulamalı Bilimler Yüksekokulu Muhasebe Bölümü öğrencilerinin TÜRMOB etik yönetmeliğini nasıl algıladıkları ve temel etik değerler konusundaki tutumları araştırılmıştır. Bu amaçla öğrencilerden birincil veri toplamak amaciyla Yalçın (2011) tarafindan geliştirilen anket formu kullanılmıștır. Anket formunda kullanılan ifadeler, TÜRMOB etik yönetmeliğinde tüm meslek mensuplarının uyması gereken ilkeler olarak belirlenen, dürüstlük, tarafsızlık, mesleki yeterlilik ve özen, gizlilik ve mesleki davranış ilkelerine dayalı olarak hazırlanmıştır. Katılımcılar anket formundaki ifadelere tutum derecesini Likert tipi 5'li ölçek doğrultusunda belirtmiştir. Verilerinin değerlendirilmesinde betimsel analiz kapsamında değişkenlere ilişkin aritmetik ortalama ve standart sapma değerleri incelenmiştir. Yordamsal analiz kapsamında ise katılımcıların verdikleri cevapların fark analizleri bağımsız örnek t-testi (2-tiled) ve tek yönlü anova ile yapılmıştır. Anket geri dönüş oranı \% 59 olarak gerçekleşmiş̧tir. Anketin güvenirlik çalışması, iç tutarlık katsayı (Cronbach alpha) değerleri hesaplanarak yapılmıştır. Anket formunun tamamı ve Etik Değerler Ölçeği yüksek derecede güvenilir iken, Genel Durum Ölçeği oldukça güvenilirdir.

Katılımcıların mezuniyet sonrası mesleki stajını başlatmayı düşündükleri; muhasebe meslek mensubu olmanın zor olmasına rağmen bunu istedikleri; gelecekte belge sahibi olarak kendi işyerinde çalışmayı istedikleri görülmektedir. Bu konudaki ifadelere ticaret lisesi mezunları daha yüksek oranlarda katılım göstermişlerdir. Diğer taraftan öğrencilerin bağımsız denetçi, devlet memurluğu ve öğretmenlik / akademisyenlik konusunda kararsız oldukları görülmektedir. Bununla birlikte katılımcılar muhasebe meslek mensubu olmanın gelecekleri açısından önemli olduğunun farkındadırlar. Bu yüzden katılımcıların büyük bir kısmının hedef koyup çaba harcadıkları söylenebilir.

TÜRMOB etik yönetmeliği doğrultusunda hazırlanan ve dürüstlük, tarafsızlık, mesleki yeterlilik ve özen, gizlilik ve mesleki davranış başlıklarında topladığımız ifadelere katılımcıların genelde katılım yönünde tutum belirttikleri görülmektedir. Ticaret lisesi mezunları anket formundaki ifadelere diğer programlardan mezun olan katılımcılara oranla daha yüksek ortalamalarla katılım yönünde tutum belirtmişlerdir. Diğer taraftan üst sınıflarda eğitim gören öğrencilerin ortalamaları alt sınıflardaki öğrencilere göre daha yüksektir. Ayrıca Yalçın (2011) çalışmasında meslek mensuplarından alınan cevapların ortalamaları ile bu çalışmada elde edilen cevapların ortalamaları genel olarak karşılaştırıldığında, meslek mensuplarından elde edilen ortalamaların daha yüksek olduğu sonucuna ulaşılmıştır. Sonuç olarak ticaret lisesinden mezun olan katılımcıların etik değerler konusunda daha bilinçli oldukları ve öğrencilerin eğitim aşamaları ilerledikçe etik bilinçlerinin arttığı görülmektedir. 


\section{KAYNAKLAR}

Akbaş, Halil, Emre - Özsözgün, Çalışkan, Arzu - Özarslan, Emel (2009), "Muhasebe Mesleğinde Etik Algısı ve Etik Dışı Davranışlarla İlişkisi: İşletme Bölümü Öğrencileri Üzerine Bir İnceleme", Öneri, Cilt 8, Sayı 32, Temmuz, ss. 175-184.

Akdoğan, Habib (2003), Muhasebe Meslek Etiğinin Kamunun Aydınlatılmasındaki Önemine Meslek Mensuplarının Yaklaşımları, Anadolu Üniversitesi Yayın No: 1470, Eskişehir.

Akdoğan, Habib (2005), "Muhasebe Meslek Etiğinde Teolojik ve Deontolojik Yaklaşımların Karşılaştırılması", Süleyman Demirel Üniversitesi İktisadi ve İdari Bilimler Fakültesi Dergisi, Cilt 10, Sayı 1, ss. 295-300.

Alpar, Reha (2003), Uygulamalı Çok Değişkenli İstatistik Yöntemlere Giriş I, Nobel, Ankara.

Arslan, Hasan - Gökoğlan, Kadir - Bulut, Mustafa (2018), "Dicle Üniversitesi Sosyal Bilimler Meslek Yüksekokulu Öğrencilerinin Muhasebe Meslek Etiği Algıları Üzerine Bir Araştırma”, Elektronik Sosyal Bilimler Dergisi, Cilt 17, Sayı 65, ss.278-294.

Ay, Ünal (2003), İşletmelerde Etik ve Sosyal Sorumluluk, Nobel Kitabevi, Adana.

Aydın, Pehlivan, İnayet (2002), Yönetsel Mesleki ve Örgütsel Etik, Pegem Yayıncılık, İstanbul.

Aymankuy, Yusuf - Sarığlan, Mehmet (2005), "Muhasebe Meslek Mensuplarının Meslek Etiğine Yaklaşımları ve Balıkesir İl Merkezinde Bir Uygulama”, Balıkesir Üniversitesi Sosyal Bilimler Enstitüsü Dergisi, Cilt 8, Sayı 14, ss. 23-45.

Badiou, Alain - (Çev: Birkan, Tuncay) (2004), Etik, Kötülük Kavrayışı Üzerine Bir Deneme, Metis Yayınları, İstanbul.

Ceylan, Pınar - Terzi, Serkan (2016). "Muhasebe Eğitimi Alan Öğrencilerin Meslek Etiği Algılamalarının İncelenmesi: Çankırı Karatekin Üniversitesi Örneği”, Kastamonu Üniversitesi İktisadi ve İdari Bilimler Fakültesi Dergisi, Sayı 13, ss. 312-327.

Daştan, Abdulkerim (2009), "Etik Eğitiminin Muhasebe Eğitimindeki Yeri ve Önemi: Türkiye Değerlendirmesi”, Marmara Üniversitesi İ.İ.B.F Dergisi, Cilt 26, Sayı 1, ss. 281-311.

Daştan, Abdulkerim - Bayraktar, Yaşar - Bellikli, Uğur (2015), "Muhasebe Mesleğinde Etik İkilem ve Etik Karar Alma Konularında Farkındalık Oluşturma: Trabzon İlinde Bir Araştırma”, Atatürk Üniversitesi İktisadi ve İdari Bilimler Dergisi, Cilt 29, Sayı 1, ss. 63-82.

Dinç, Engin - Tunçer, Mehmet (2015), "Muhasebe Meslek Mensuplarının Etik Duyarlılıkları ile İlgili Vergi Müfettişlerinin Algılarına Yönelik Bir Araştırma", International Journal of Economic and Administrative Studies, Y1 7, Say1 14, ss. 317-337.

Ertaş, Fatih, Coşkun - Arslan, Coşkun, Mihriban (2009), "Bağımlı ve Bağımsız 
Muhasebecilerin Meslek Etiği Algılama Düzeylerine İlişkin Bir Araştırma”, Muhasebe ve Denetime Bakış, Sayı 27, ss. 23-42.

Fidan, Meral Erol - Şubaşı, Şerife (2014), "Muhasebe Meslek Mensubu Adaylarının Etik Algıları", Muhasebe ve Finansman Dergisi, Say1 64, ss. 111-129.

Kalaycı, Şeref (edit). vd. (2006), SPSS Uygulamalı Çok Değişkenli İstatistik Teknikleri, Asil Yayın Dağıtım, İstanbul.

Karabınar, Selahattin - Zülküf Çevik (2014). "Türkiye'deki Zorunlu Muhasebe Meslek Kurallarının Ahlak Yaklaşımları Açısından İncelenmesi", Muhasebe Bilim Dünyası Dergisi, Cilt 6, Sayı 2, ss. 29-44.

Kıll1, Mustafa - Türkoğlu, Hasan - Gülmez, Cançağ (2018), "Muhasebe Meslek Mensuplarının Etik Algısı: Malatya İlinde Bir Araştırma", Muhasebe ve Vergi Uygulamalar1 Dergisi, Cilt 11, Say1 1, ss. 45-62.

Kısakürek, Mustafa - Alpan, Nesrin (2010), "Muhasebe Meslek Etiği ve Sivas İlinde Bir Uygulama" MUFAD Muhasebe ve Finansman Dergisi, Sayı 47, ss. 213-228.

Kurnaz, Niyazi - Gümüş, Yusuf (2010), "Muhasebe Bölümü Öğrencilerinin Muhasebe Mesleği ile İlgili Etik Dışı Davranışlara İlişkin Algı Analizi: Dumlupınar Üniversitesi Uygulamalı Bilimler Yüksekokulu Örneği”, Muhasebe ve Finansman Dergisi, Sayı 46, ss. $157-174$.

Kurt, Ganite - Okan, Pınar - Başer, Furkan (2010), "Muhasebe Meslek Mensubu Olabilecek Öğrencilerin Meslek Etiği Konusundaki Algılama ve Eğilimlerinin Belirlenmesi" Muhasebe ve Vergi Uygulamaları Dergisi, Cilt 3, Sayı 1, ss. 1-20.

Kutlu, Hüseyin, Ali (2008), "Muhasebe Meslek Mensupları ve Çalışanlarının Etik İkilemleri: Kars ve Erzurum İllerinde Bir Araştırma”, Ankara Üniversitesi SBF Dergisi, Cilt 63, Say1 2, ss. 144-170.

Özdamar, Kazım (1997), Paket Programlar ile İstatistiksel Veri Analizi I, T.C. Anadolu Üniversitesi Yayınları, No: 1001, Fen Fakültesi yayınları, No: 11, Eskişehir.

Peker, Ali Aykut - Özdemir, Şefik - Polat, Yusuf - Karakışla, Enver (2016). "Türkiye'de Muhasebe Eğitimi, Etik Değerler Ve Meslek Etiği Üzerine Literatür Taraması", International Journal of Human Sciences, Cilt 13, Say1 1, ss. 869-880.

Selimoğlu, Kardeş, Seval (2006), “Türk Muhasebe Uygulamalarında Etik”, Mali Çözüm, Kasım, Sayı 61, ss. 437-456.

Sözbilir, Naciye (2000), Türkiye'de Muhasebe Uygulamalarında Etiksel Boyutlar, Kocatepe Üniversitesi Yayınları No: 26, Afyon.

Tevrüz, Suna (2007), İş Hayatında Etik, Beta Yayınları, İstanbul.

TÜRMOB (2001), Serbest Muhasebecilik, Serbest Muhasebeci Mali Müşavirlik ve Yeminli 
Mali Müşavirlik Meslek Ahlâk Kuralları ile İlgili Mecburi Meslek Kararı, Resmi Gazete, 18.10.2001, Say1: 24557.

TÜRMOB (2007), Serbest Muhasebeciler, Serbest Muhasebeci Mali Müşavirler ve Yeminli Mali Müşavirlerin Mesleki Faaliyetlerinde Uyacakları Etik İlkeler Hakkında Yönetmelik, Resmi Gazete, 19.10.2007, Sayı: 26675.

Uyar, Süleyman - Kahveci, Ata - Yetkin, Murat (2015), “Öğrencilerin Muhasebe Meslek Etiği Algısı: ALTSO Meslek Yüksekokulu Örneği”, Niğde Üniversitesi İktisadi ve İdari Bilimler Fakültesi Dergisi, Cilt 8, Sayı 2, ss. 237-247.

Yalçın, Selçuk (2011), "Muhasebe Meslek Mensupları ve İşletmelerin Etik Konusunda Tutumları: Türkiye Araştırması", Muhasebe ve Finansman Dergisi, Sayı 52, ss. 47-66.

Yanık, Ahmet - Yıldız, Ferah - Günce, Nurcan (2013),"A Study on the Business Ethics in Accounting and the Perception of Ethics by Professional Candidates", International Research Journal of Finance and Economics, Sayı 113, ss. 29-40.

Yel, Tülay (2018), "Muhasebe Meslek Mensuplarının Meslek Etiği Hakkındaki Görüşlerine İlişkin Bolu'da Bir Araştırma”, AİBÜ Sosyal Bilimler Enstitüsü Dergisi, Cilt18, Sayı 2, ss. $165-184$

Yıldız, Fehmi (2002), Muhasebe Mesleğinde Meslek Ahlâkı, Der Yayınları, İstanbul.

Yılmaz, Erdal - Yıldırım, Suat - Bahar, Hüseyin Hüsnü (2015), “Serbest Muhasebeci Mali Müşavirlerin Mesleki Etik Algısı: Samsun Örneği”, Muhasebe ve Finansman Dergisi, Say1 65, ss. 27-41.

Yücel, Recep - Kartal, Cihat (2014), "Muhasebecilerin Mesleki Uygulamalarındaki Etik Algılarına İlişskin Bir Araştırma", Kırıkkale Üniversitesi Sosyal Bilimler Dergisi, Cilt 4, Say1 2, ss. 123-148. 
